\title{
Recent advances in the development and evaluation of molecular diagnostics for Ebola virus disease
}

John Tembo, Edgar Simulundu, Katendi Changula, Dale Handley, Matthew Gilbert, Moses Chilufya, Danny Asogun, Rashid Ansumana, Nathan Kapata, Francine Ntoumi, Giuseppe Ippolito, Alimuddin Zumla \& Matthew Batesthe PANDORA-ID-NET consortium

To cite this article: John Tembo, Edgar Simulundu, Katendi Changula, Dale Handley, Matthew Gilbert, Moses Chilufya, Danny Asogun, Rashid Ansumana, Nathan Kapata, Francine Ntoumi, Giuseppe Ippolito, Alimuddin Zumla \& Matthew Batesthe PANDORA-ID-NET consortium (2019): Recent advances in the development and evaluation of molecular diagnostics for Ebola virus disease, Expert Review of Molecular Diagnostics, DOI: 10.1080/14737159.2019.1595592

To link to this article: https://doi.org/10.1080/14737159.2019.1595592

Accepted author version posted online: 27

Mar 2019.

Submit your article to this journal $2 \pi$

View Crossmark data 
Publisher: Taylor \& Francis

Journal: Expert Review of Molecular Diagnostics

DOI: $10.1080 / 14737159.2019 .1595592$

\section{Review}

Recent advances in the development and evaluation of molecular diagnostics for Ebola virus disease

John Tembo ${ }^{1,}$ Edgar Simulundu², Katendi Changula ${ }^{2}$, Dale Handley ${ }^{3}$, Matthew Gilbert ${ }^{3}$, Moses Chilufya ${ }^{1}$, Danny Asogun ${ }^{4}$, Rashid Ansumana ${ }^{5}$, Nathan Kapata ${ }^{6}$, Francine Ntoumi ${ }^{7}$, Giuseppe Ippolito ${ }^{9}$, Alimuddin Zumla ${ }^{8,10}$, Matthew Bates ${ }^{1,3,8 *}$ and the PANDORA-ID-NET consortium

${ }^{1}$ HerpeZ, University Teaching hospital, Lusaka, Zambia

${ }^{2}$ University of Zambia School of Veterinary Medicine, Lusaka, Zambia

${ }^{3}$ School of Life Sciences, University of Lincoln, Lincoln, United Kingdom

${ }^{4}$ Lassa fever research institute, Irrua University Teaching Hospital, Nigeria

${ }^{5}$ Mercy Hospital, University of Njala, Sierra Leone

${ }^{6}$ Zambia National Public Health Institute, Lusaka, Zambia

${ }^{7}$ Fondation Congolaise pour la Recherche Médicale, Brazzaville, Republic of Congo

${ }^{8}$ Centre for Clinical Microbiology, Division of Infection and Immunity, University College London (UCL), London, UK

${ }^{9}$ Lazzaro Spallanzani National Institute for Infectious Diseases, Rome, Italy

${ }^{10}$ National Institute of Health and Research Biomedical Research Centre, UCL Hospitals National Health Service Foundation Trust, London, UK

*Corresponding author: Matthew Bates, Joseph Banks Laboratories, School of Life Sciences, University of Lincoln, Lincoln, Lincolnshire. LN6 7TS, Tel: +44( 0)1522835228, mbates@lincoln.ac.uk 


\begin{abstract}
Introduction: Viruses from the family Filoviridae can cause viral haemorrhagic fevers (VHFs), including Ebola virus disease (EVD) and Marburg virus disease (MVD). The 2014-16 outbreak of EVD in West Africa resulted in 11,308 deaths, representing a case fatality rate of $39.5 \%$. During the outbreak, only $60 \%$ of patients were laboratory confirmed and global health authorities have identified the need for accurate and readily deployable molecular diagnostics as an important component of the ideal response to future outbreaks, to quickly identify and isolate patients.
\end{abstract}

Areas covered: Following the outbreak in West Africa, various molecular diagnostic assays to detect EVD have been developed, to detect genes, proteins/antigens and antibodies associated with the infection. Currently PCR based techniques and rapid diagnostic tests (RDTs) that detect antigens specific to EVD infections dominate but recent advances in biosensor technologies have led to novel approaches for the development of EVD diagnostics. This review summarises the literature and available performance data of currently available molecular diagnostics for ebolavirus, identifies knowledge gaps and maps out future priorities for research in this field.

Expert opinion: While there is now a plethora of diagnostic tests for EVD at various stages of development, there is an acute need for studies to compare the clinical performance of these EVD diagnostics. The sporadic nature of EVD outbreaks makes this extremely challenging, demanding pragmatic new modalities of research funding and ethical/institutional approval, to enable responsive research in outbreak settings. Retrospective head-to-head diagnostic comparisons could also be implemented using biobanked specimens, providing this can be done safely.

Keywords: Ebola, Diagnostics, EVD, outbreaks, preparedness

\title{
Article highlights
}

- Rapid molecular diagnostic assays for EVD are a key component of an effective outbreak response.

- Molecular diagnostics for Ebolaviruses are abundant and being rapidly developed, but there is very little evidence to suggest which tests are clinically most accurate and appropriate.

- Validating EVD diagnostic assays against an established gold standard is very difficult in the context of an ongoing outbreak.

- Head-to-head comparison of different diagnostic tests using biobanked specimens requires strong international leadership and equitable collaboration.

- Regular clinical surveillance is necessary and should be affordably embedded into existing national health programmes in African countries and beyond. 


\section{Introduction}

Viruses from the family Filoviridae can cause viral haemorrhagic fevers (VHFs), including Ebola virus disease (EVD) and Marburg virus disease (MVD)[1]. There are five known Ebolavirus species, namely Zaire ebolavirus, Sudan ebolavirus, Taï Forest ebolavirus, Bundibugyo ebolavirus and Reston ebolavirus, represented by the following viruses respectively, Ebola virus (EBOV), Sudan virus (SUDV), Taï Forest virus (TAFV), Bundibugyo virus (BDBV) and Reston virus (RESTV)[2]. There is also one newly proposed ebolavirus isolated from insectivorous bats, Bombali virus (BOMV), as yet not known to cause human disease[3]. There is only one known marburgvirus species, Marburg marburgvirus, with two known viruses, Marburg virus (MARV) and Ravn virus (RAVV)[2]. There is a third genus within the Filoviridae called Cuevavirus that is not linked to VHF in humans.

The EVD epidemic in West Africa originated in Guinea in late 2013 and over the course of two years resulted in the deaths of over 11,000 people [4], mainly in Guinea, Sierra Leone \& Liberia. This devastating outbreak caught the health systems of the affected countries and the wider global health community, completely unprepared, both in terms of the immediate response and in terms of our broader readiness and the available infection control tools for EVD [5]. Despite Ebolavirus having been discovered over 4 decades ago, at the start of the West African outbreak there was no regulator-endorsed vaccine, diagnostic or therapeutic for this deadly infectious disease, for which the mean case fatality rate is $60.4 \%$ (Range $24.8 \%-89.5 \%$ ) (data extracted from the CDC table of past EVD outbreaks, excluding isolated and exported cases, with addition of latest update from North Kivu outbreak in DRC as of $17^{\text {th }}$ Dec 2018: 542 cases and 319 deaths) [6, 7]. Before the outbreak in West Africa, previous outbreaks had occurred exclusively in Central Africa, and had been largely limited to the 10s or low 100 s of cases, through clinical diagnosis and isolation of suspected cases and their contacts, using classical epidemiological and infection control techniques. For this reason, ebolavirus was not considered a public health priority and global health research and programme funding concentrated on controlling established endemic infectious diseases such as HIV, TB and Malaria [8]. Furthermore, there are intrinsic challenges to studying Ebola; any laboratory research on live ebolavirus requires BSL-4 facilities, typically led by national government health and defence institutions, that have many competing priorities. Then with respect to clinical studies, prior to the West Africa epidemic, outbreaks have previously been contained relatively quickly, making the standard 6-18 month research modality of writing grant proposals and winning funding obsolete. The scale of the West African epidemic, which lasted for over two years, induced a swift response from the major research and programme funding bodies to provide more funds for both preparedness and research activity [8]. For this reason it was possible to initiate some clinical studies of potential interventions, but these were largely limited to preliminary validations, and in some cases occurred during the tail end of the epidemic when case numbers were very low [9]. There is a great need for a coordinated global response to ensure that wherever and whenever the next Ebola outbreak might be, research studies are planned and ready to implement within a timeframe of just a few weeks.

The need for accurate diagnostic tests is at the vanguard of the response to an ebolavirus outbreak, as they are the first line of defence in the early days and are a pre-requisite for subsequent vaccine and therapeutic trials. Beginning in August 2014 and over the next year, as a direct response to the West African outbreak and the threat it posed to global health security, the Food and Drug Administration FDA in the U.S granted emergency use authorization (EUA) for 10 different molecular diagnostic tests for Ebola [10], comprising nine Real Time Polymerase Chain Reaction (RT-PCR) based assays and one rapid antigen detection test. Several of these were used in the field in West 
Africa, giving rise to preliminary performance data including some head-to-head comparisons. In this review we analyse the available data on the performance of these and more recent ebolavirus assays. We then identify the current knowledge gaps and present our opinion on future priorities for diagnostic development and diagnostics research for EVD.

\section{Ebola transmission dynamics}

When considering how molecular diagnostics might be developed and used to control ebolavirus outbreaks we must first consider the nature of the virus and its transmission dynamics. Ebolaviruses are helical enveloped negative-sense RNA viruses that replicate in the cytoplasm of infected cells and a number of outbreaks of EVD have been associated with hunting and processing of bush meat[11]. Whilst epidemiological data that links index cases to contact with bats [12] (which can be infected experimentally [13]), extensive efforts have so far failed to isolate Ebolavirus from bats, although ebolavirus RNA and/or antibodies (?) have been detected in a number of bat species [1417]. This is in contrast to Marburg virus, which has been successfully isolated from bats $[18,19][4]$. In human infection early cell targets are monocytes, macrophages and dendritic cells but the cell tropism of ebolavirus is broad and it subsequently disseminates and infects a wide range of cell types including hepatocytes, adrenal cortical cells, fibroblasts and endothelial cells [20]. Ebolavirus is shed in a wide range of body fluids, including sweat, which could account for documented secondary cases reporting physical contact but not with body fluids or mucosal membranes [21]. The West African outbreak was largely driven by 'super-spreaders', with $61 \%$ of cases contracted directly from just $3 \%$ of cases [22] and if any human cases could produce infectious aerosols they might be from within this $3 \%$, but the evidence for this is weak. There have also been isolated cases where no physical contact is reported, although these seem most likely due to fomites and contact with contaminated surfaces and are in no way conclusive of aerosol transmission. There are also several cases of nosocomial infection in the U.S and Spain, where all safety protocols were in place yet it has not been possible to identify the precise route of transmission [21]. Animal studies have demonstrated transmission of Ebola from pigs to macaques without direct contact [23] but the studies didn't rule out transmission via contact with bodily fluids or fomites. While it may be theoretically possible that if a human case shed sufficient virus in the respiratory tract and the virus could be released in aerosols, there is no conclusive evidence proving this and most epidemiological evidence is strongly against the likelihood of aerosol transmission.

Another interesting consideration from a diagnostic perspective is the existence of IgG seropositive asymptomatic case contacts and other healthy blood donors who have no history of severe Ebolalike disease. A study of case contacts in Sierra Leone reported Ebola IgG seroprevalence at $11 \%$ [24]. In a recent study from Boende Health Zone in the DRC (site of the 2014 EVD outbreak) a range of serological tests were used to screen 565 health workers (not restricted to case contacts), among whom 234 (41.4\%) were sero-reactive to at least one EBOV protein [25]. Among these cases, sera from a small minority (16) could neutralize a recombinant HIV virus expressing EBOV glycoprotein (GP). It is now widely accepted that in a minority of cases EBOV can cause a mild, sub-clinical or asymptomatic but replicative infection [26, 27]. Epidemiologically it is difficult to argue that this accounts for seroprevalence rates observed in healthy populations with no history of EVD disease or case-contact, data from the DRC suggest EBOV IgG seroprevalence rates of $11 \%$ among the general population [28] and up to $18 \%$ among Efe pigmy populations [29]. In Sierra Leone, a retrospective biobank study of patients with suspected Lassa virus (LASV) infection (but who were LASV IgM and malaria negative) found low titre Ebola IgM in $8.6 \%$ of all cases [30]. Other non-mutually exclusive theoretical explanations for population level seroprevalence could include the idea that the EBOV antigens used could be cross-reacting with antibodies from novel/unknown filovirus species that cause only mild or sub-clinical infection, the idea that there could be cross-reactivity with 
homologous proteins of other viruses such as the GP proteins of arenaviruses or bunyaviruses [31] or simply unrelated non-specific binding/noise due to issues with assay use or design and validation.

A final consideration is the issue of long-term shedding of ebolavirus in EVD survivors. In patients who survive Ebola, viraemia usually becomes undetectable around 2 weeks after the report of first symptoms [32], although cases of persistent positive results in asymptomatic survivors have been documented in both pregnant women [33] and semen specimens [34-36], raising questions about the possibility of vertical or horizontal sexual transmission from survivors. Between March $20^{\text {th }} 2015$ and March $16^{\text {th }}$ 2016, there were 8 documented 'flare-ups' of EVD thought to have arisen from survivors infecting close contacts. In 4 of these cases, the suspected body fluid was semen, from men discharged from Ebola treatment units (ETUs) between 1.5-17 months previously. There is one well-documented case of vertical transmission, in which a 9 month old baby who died tested positive for EBOV by oral swab. The mother and father were IgG positive (but IgM negative) and tested positive for EBOV RNA in breast milk and semen respectively. Both were almost certainly examples of undiagnosed survivors. Sequence data confirmed the isolate from the baby was closely related to that detected in the breast milk, but was more distant from that detected in the semen [37] [34]. A study on serial samples collected across both of the 1996 EVD outbreaks in Gabon (caused by EBOV), demonstrated that $11 / 24$ case contacts (with known exposure to infected materials from fatal and non-fatal cases) developed Ebola-specific IgM and IgG responses at 23 days post exposure. The paper also presents nested PCR results for two of these sero-converting asymptomatic cases, showing positive detection of Ebola virus RNA (confirmed by sequencing of the 298bp fragment), waning by day 19 and day 23 respectively, suggestive of replicative but asymptomatic infection, although the paper does not mention any effort to culture virus. [38]. There is a need to explore this idea further during contemporary outbreaks, using the latest molecular tools. A better fundamental understanding of the prevalence, virology and immunology of such cases might inform on diagnostic or vaccine design, to the operational aspects of using molecular diagnostics in EVD control.

\section{Molecular diagnostics for Ebola virus disease}

Diagnostic assays based on the detection of Ebola-specific antibodies are of limited use in the diagnosis and management of EVD because the immune response to primary infection only becomes detectable around three weeks post-exposure [38] and a significant minority of the healthy population are IgG seropositive [39]. For this reason most of the efforts to develop molecular diagnostic tests have focussed on the detection of either antigenic proteins or nucleic acid (Tables 1 \& 2). We drew up tables using information from diverse sources including published articles, government agency reports, product inserts and manuals and through direct contact with companies or through their websites. There are at least 18 companies or organizations with Ebolavirus RT-PCR assays at various stages of development (Table 1), and a further 9 companies developing antigen-based rapid diagnostic tests (RDTs) (Table 2). The over-arching vision of how these different diagnostic technologies might be employed is that the much cheaper and easier to use RDTs, which should not require cold-chain reagents, would be used as a 'rule out' (high sensitivity, but with possibly lower specificity) triage tool at community health posts and by contact tracing teams, requiring no laboratory infrastructure and implementable by large numbers of relatively low-skilled personnel. Patients who flag positive would then be referred to larger health centres with laboratory and PCR facilities. For confirmatory testing WHO recommends RT-qPCR tests [40] that are generally perceived to be more specific than RDTs [41]. During the first 3 days after

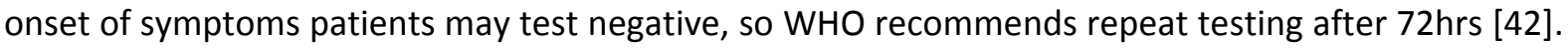


RT-qPCR assays typically require cold-chain reagents and take 1-3hrs, depending on throughput and batching, but in real world settings reporting times are often several days [43] and factors like specimen transport, human resources and supply chain are more important causes of delay than hands-on analysis time [44]. The requirement of intravenous blood is a risk for healthcare worker transmission, compared with taking oral swabs or other non-invasive specimens [45]. A retrospective modelling study suggested that using dual screening with both a highly sensitive RDT, followed by a highly specific PCR assay, could have reduced the epidemic in Sierra Leone by up to a third [43]. However, there may be as yet unknown filovirus species that may not be detected by the current molecular diagnostics, as occurred with the first outbreak of BDBV, where nucleotide difference between BDBV and TAFV (its closest relative) was 32\%[46]. It must be noted here that this was not the case for the newly discovered BOMV[3].

Before the ebolavirus outbreak in West Africa, both EVD outbreak response \& research in selected BSL-4 facilities relied on in-house RT-PCR and RT-qPCR assays, so the rapid proliferation of competing commercial molecular diagnostics for EVD is welcomed, with many companies adapting the platforms and chemistries they have developed for other infectious disease assays [47, 48]. However, this rapid increase in the quantity of novel diagnostics means we have to choose which one/s to use and provide evidence for that decision. Classically, any novel diagnostic test should be evaluated on genuine clinical specimens (prospectively collected or biobanked) against an established gold standard. For Ebola, this poses three challenges: 1) The established gold standard is culture (followed by electron microscopy, histological and molecular analysis), requiring BSL-4 facilities, which is impractical in outbreak settings, 2) Ebola outbreaks are sporadic, and so there is no steady supply of patients on which to conduct clinical diagnostic trials and 3) Biobanked specimens are finite and their use in diagnostic evaluations is a significant public health risk unless conducted in a BSL-4 facility. For these reasons, there have been very few head-to-head comparisons of different diagnostic tests. For all diagnostics in which the RNA extraction step is not integrated into a self-contained cartridge [47, 48], the RNA extraction protocol used [49] and the specimen type tested [50] present additional sources of variation, which might impact diagnostic test accuracy. A validation study undertaken in 2004 (thus not including many of the newer assays) found that the impact of RNA extraction kit was minimal, but that results varied significantly between the 24 laboratories involved in the study. Whilst $78.6 \%$ of labs were able to detect ebolavirus at $2.2 \times 10^{5}$ copies $/ \mathrm{ml}$, only $46 \%$ of labs were able to detect the virus at concentrations lower than $10^{4}$ copies $/ \mathrm{ml}$ [49]. A more recent study sent out 11 standards (10-fold serial dilutions of heat inactivated tissue culture supernatants) to 83 different laboratories (including 21 labs from Sierra Leone and Guinea), who returned 106 datasets (some labs used multiple assays). The $10^{-4}$ dilution was detected in $89.6 \%$ (95/106) of datasets, whereas the $10^{-5}$ dilution was detected in just $79.2 \%(84 / 106)$ of datasets [51]. Another striking finding is that for any given dilution, the range of $\mathrm{Ct}$ values is highly variable, with the interquartile range spanning from about 5 cycles (at titres of $10^{-3}$ and above) up to 10 cycles or more for lower dilutions. Unfortunately the viral genome copies of these standards are not reported, which makes it difficult to correlate these results with known detection limits in clinical specimens. The most commonly used assays by far were the kits produced by Altona Diagnostics (Table 1 ), accounting for $44 \%(47 / 106)$ of datasets overall and $85 \%(47 / 55)$ of commercial assays used. For this reason it makes sense that we first look at the available data on the performance of these assays and their use during the West Africa epidemic (section 3.1). The available data on other assays is severely limited, but in this review we shall also dedicate a section (section 3.2) to the Xpert Ebola assay (Cepheid, Sunnyvale, CA, U.S), because this cartridge-based 
assay is the primary assay being using in the current EVD outbreak in the Democratic Republic of Congo (at time of writing: Mar 2019).

\subsection{Altona Diagnostics RT-qPCR assays}

Altona Diagnostics (Germany) initially developed two different ebolavirus diagnostics kits, the 'RealStar ${ }^{\circledR}$ Filovirus Type RT-PCR Kit 1.0', which can differentiate between all 5 known ebolavirus species and marburg virus, and the 'RealStar ${ }^{\circledR}$ Filovirus Screen RT-PCR Kit 1.0', which can detect either ebolavirus or marburgvirus, but cannot differentiate between ebolavirus species. This latter 'Screen' assay is the one that has been most used in West Africa. Subsequently Altona Diagnostics have developed a third assay, the RealStar Zaire Ebolavirus RT-PCR kit 1.0', which has been designed to specifically target EBOV, which was the causal agent of both the West African epidemic and the four concurrent/subsequent outbreaks in the DRC. Non-multiplex assays tend towards greater sensitivity and improved signal-to-noise ratios at low viral RNA concentrations [42]. The 'Screen' assay has a 95\% LOD of 500-1500 copies/ml, whereas the 'Type' assay was shown in one study to have a 95\% LOD of 6250 copies/ml (Table 1). The 'Zaire' assay is currently registered for Research Use Only (RUO) and at the time of going to print, Altona Diagnostics had not released any LOD data.

Evaluation of capillary blood (a safer and more convenient finger prick blood collection option) showed that yields were lower than using venous blood, though this finding has been criticised as the authors did not correct for blood volume, although they argue overall viral concentration in blood is the same whether obtained from the vein or capillary [45]. All Altona assays can be used with multiple RNA-extraction and Real Time PCR platforms (Table 1). A large observational study in Guinea using the 'Screen' assay showed that higher viral loads (as approximated by Cq values) are associated with higher case fatality ratios [52]. The same study showed that mortality was highest in young children $>5$ years of age, and those aged $>45 \mathrm{yrs}$, while among children aged 5-14 years, malaria parasitaemia was associated with increased risk of mortality [52]. By contrast, in another study that also included adults and children, higher levels of malaria parasitaemia were found to be linked with a reduced risk of mortality [53].

The RealStar ${ }^{\circledR}$ 'Screen' assay has been used as the 'Gold Standard' in several validation studies, but studies comparing multiple Ebola diagnostic tests in parallel have demonstrated significant levels of discrepancy between different tests [54]. In this Lancet study a total of 277 biobanked EDTA whole blood samples were re-tested with the RealStar ${ }^{\circledR}$ 'Screen' assay and the Corgenix ReEBOV Antigen Rapid test kit. Their analysis showed that where samples were previously shown to be positive by these two different tests, subsequent re-analysis by RT-PCR was highly reproducible, using both the Altona and Trombley assays (an in-house assay developed by the U.S military [55]). However, among 16 samples that were previously discordant (RDT +ve, Altona -ve), the Trombley assay identified 6 positives, one of which was now also positive by Altona. Similarly, among a set of 18 samples that were initially concordant negatives (RDT-ve, Altona-ve), there were now 3 positives with the Trombley assay [54]. These findings illustrate that classic molecular diagnostic developer's conundrum; no two assays ever perform exactly the same. These results point towards an improved sensitivity for the in-house Trombley assay, compared with the Altona assay, and indeed during the West Africa outbreak, the PHE mobile lab in Freetown switched from using the Altona assay to the Trombley assay due to 'performance issues' [56]. Similarly, other evaluations have identified probable false negatives using the RealStar ${ }^{\circledR}$ Screen assay $[57,58]$. However, these results are preliminary and often based on opportunistic data collected during outbreak response, as opposed to rigorously designed comparative clinical diagnostic trials. 


\subsection{Xpert $^{\circledR}$ Ebola}

The GeneXpert platform developed by Cepheid (Sunnyvale, CA) is a cartridge-based close-to-pointof-care Real Time PCR machine. In the global health sector the platform is primarily known for the Xpert MTB/RIF assay, which is WHO-endorsed and is being rolled out across several countries for routine TB care, although the operational effectiveness of the assay in different settings and patient groups is still much debated [59]. Given that the GeneXpert platform is now widely available and because Cepheid's Ebola assay is currently being used in the present DRC outbreak, we chose to review the assay and all available data. In March 2015 the 'Xpert ${ }^{\circledR}$ Ebola' assay was granted 'emergency use authorization' (EUA) [60] and the assay was used by some labs during the West Africa outbreak [61-63]. The company are one of the few to publish a 'list-price' with each cartridge priced at $\$ 19.80$ and the 4-channel GeneXpert machine costing around \$20,000 (inclusive of low and middle income country (LMIC) discount). The assay targets two ebolavirus genes, that encode the nucleoprotein (NP) and glycoprotein (GP), contains internal controls and is interpreted automatically, minimizing operator bias in reporting results. Unlike many PCR-based assays, the cartridges and lysis buffer can be shipped at $2-8^{\circ} \mathrm{C}$, so do not require freezer storage. The selfcontained cartridges allow samples to be processed independently of each other (without batching) and offer a high degree of containment and biosafety, as the first step involves addition of the sample to $2.5 \mathrm{ml}$ lysis buffer containing $4.5 \mathrm{M}$ guanidinium thiocyanate [32], which inactivates the virus disrupting the capsid and lipid envelope releasing the DNA during a 10-20 minute incubation at room temperature. The specimen is then added to the reaction cartridge, which is sealed for the duration of the analysis and can be discarded and incinerated after use. The Xpert ${ }^{\oplus}$ Ebola assay is most sensitive at detecting the NP gene, with median cycle thresholds being roughly $5 \mathrm{Cq}$ values lower for NP than for GP $[62,64]$. The software scores a discrepant result as 'indeterminate', requiring repeat testing and preliminary data suggests the $\mathrm{Xpert}^{\circledR}$ Ebola assay is up to a log more sensitive than the Altona assays [32](Table 1), but the only way to confirm differences in analytical sensitivity between two diagnostic assays is through head-to-head comparison. A comparison between the Xpert ${ }^{\oplus}$ Ebola assay and the in-house Panning ebola assay [65] did not demonstrate any significant difference in analytical sensitivity, with both assays demonstrating an LOD of 163 RNA copies/ml (equivalent to $1 \mathrm{TCID}_{50} / \mathrm{ml}$ ) [66]. A clinical validation study comparing the performance of the Xpert ${ }^{\circledR}$ Ebola assay with the in-house Trombley Zaire EBOV nucleoprotein assay, which does not perform as well as the Zaire EBOV glycoprotein assay, found the Xpert ${ }^{\circledR}$ Ebola assay to be positive in eight specimens that were negative by the Trombley Zaire EBOV nucleoprotein assay [62]. Seven of these 8 cases were all recovering convalescent patients, consistent with another study where the $\mathrm{Xpert}^{\circledR}$ Ebola assay was more sensitive than an in-house Trombley assay at detecting virus in convalescent patients [63].

Ebolavirus can persist and be isolated from semen for up to several months after infection [34, 67], although documented evidence of transmission from semen is rare. This may be due to ostracizing of Ebola survivors leading to less sexual activity and hence exposure of contacts to seminal fluid or it may suggest the risk of transmission from semen for convalescent patients is far lower than the risk of transmission from those who are acutely ill. Spiking studies have evaluated the $\mathrm{Xpert}^{\circledR}$ Ebola assay's performance in semen, which initially flagged internal control failures [64], but this was overcome by reducing the sample volume and addition of dithiothreitol (DTT) to stabilize the RNAdependent DNA polymerase. Conversely, another spiking study (using inactivated Ebola virus) did not report any indeterminate results, and determined LODs of 1000 copies $/ \mathrm{ml}$ and 275 copies $/ \mathrm{ml}$ for semen and whole blood, respectively [68].

\subsection{Comparing RT-qPCR ebolavirus assays}


In addition to Altona Diagnostics and Cepheid, there are at least an additional eleven companies or institutions that have developed RT-qPCR assays for Ebola (Table 1). For many of these assays, one is reduced to quoting the companies' internal data on assay performance, gleaned from company websites, product manuals and regulatory documentation. The analytical sensitivity of multiple assays has rarely been independently compared in parallel, controlling for the many sources of variation that exist (standards used, specimen type, thermocycling and RNA extraction platforms/protocols etc.). The most comprehensive study to date compared 6 different commercial assays (RealStar ${ }^{\circledast}$ Filovirus Screen, RealStar ${ }^{\circledR}$ Filovirus Type (Altona Diagnostics), FTD ${ }^{\circledR}$ Ebola (FastTrack Diagnostics), LightMix Ebola Zaire rRT (Roche), Lifetech Ebola Virus (Zaire 2014) \& Lifetech Lyophilized Ebola Virus (Zaire 2014))(Life Technologies), representing those available in Switzerland at the time (and 5 in-house assays) [44]. The assays were comparing using in vitro transcripts (IVTs) of both the $L$ and NP genes, derived from the sequences of two clinical isolates of Ebola from the West Africa outbreak. In this analysis, the two Altona Diagnostics assays had the highest and jointsecond highest LOD as measured by copies/ml (6250 copies/ml and 1250 copies/ml)(Table 1) [44], hence the rationale for the development of the new EBOV-specific assay [69]. The top-performing assay was the Lyophilized Lifetech assay, with an LOD of just 62.5 copies $/ \mathrm{ml}$. This assay also had the shortest thermocyling time (50 minutes) and total turnaround time (105-130 minutes) and was the only assay that could be shipped/stored at $2-8^{\circ} \mathrm{C}$ (as opposed to $-20^{\circ} \mathrm{C}$ ).

Outside of this one study, it is extremely difficult to make meaningful comparisons in terms of analytical sensitivity between different diagnostic tests. LOD data are reported using different units (RNA copies/ml, RNA copies/test, PFU/ml, PFU/test or $\mathrm{TCID}_{50} / \mathrm{ml}$ ), and standards are constructed using different templates (live virus, inactivated virus, extracted genomic RNA or IVTs) and different matrices (distilled water, tissue culture supernatant, blood, semen and urine). These factors can influence assay performance by multiple orders of magnitude [42, 70]. With all the new assays available, we really have insufficient independent analytical sensitivity data on which to make a rational choice as to which assays should be prioritised for clinical diagnostic evaluation. Just 4 of the available assays are fully integrated with dedicated platforms (Xpert ${ }^{\circledR}$ Ebola assay, Idylla ${ }^{\mathrm{TM}}$ prototype Ebola virus test and the two FilmArray assays). In addition, Altona Diagnostics have collaborated with Alere and academic partners to develop a close-to-point-of-care assay using Alere's cartridgebased Alere q system. Fully integrated diagnostic assays have several key advantages, the most important being their possible use by relatively low-skilled health workers at distant field sites close to epidemiological foci of transmission. However, there is also an argument to be made for 'open' assays that are not tied to specific diagnostic platforms. This flexibility allows different labs and national outbreak response programmes to exploit existing infrastructure without the requirement for expensive new 'lock-in' platforms, ensuring the benefits of a free-market in diagnostics are maximised, making it easier for policy and practice to keep pace with the development of new diagnostic assays [71].

Looking at other characteristics as laid out in Table 1, all but 4 of the available commercial assays, are targeted specifically to EBOV (Table 1). This focus on EBOV is understandable, as the five recent outbreaks (four in DRC (2014, 2017 \& 2018a, 2018b), and one in West Africa (2014)) were all caused by EBOV. However, the three previous outbreaks to these were all alternative filoviruses; in 2011/12 Uganda had three separate outbreaks of SUDV and the DRC had one outbreak of BDBV. Furthermore, prior to the West Africa epidemic of EBOV, the largest filovirus outbreak was the Uganda outbreak of 2000 \& 2001, in which there were 425 cases with 224 (53\%) mortalities caused by SUDV (although this has now been surpassed by the 2018b EBOV outbreak in DRC). There are currently only four commercial assays that can detect SUDV; the two original Altona assays (Screen \& Type), the Idylla ${ }^{\mathrm{TM}}$ prototype Ebola virus test (Biocartis (Mechlen, Belgium) \& Janssen Diagnostics)[72], which uses a fully integrated system along the lines of the GeneXpert, and OMScreen-ZEBOV/SUDV/MARV-RV [73], an assay developed by Sintol Ltd in Russia. The current 
outbreak (2018b) in the DRC is employing mainly the Xpert Ebola assay [74], due to its potential ease of use in field clinic settings and strong safety profile. In a future outbreak with a non-EBOV species, we would be reliant on the Altona 'Screen' assay and previously developed in-house assays developed by government special pathogens units (Table 1). Furthermore, the focus by diagnostics developers on EBOV maybe shifts the balance of probabilities; looking ahead our capacity to quickly identify and respond to EBOV outbreaks might become quite good, whereas for the other filoviruses, we might be less well prepared, and hence outbreaks caused by rarer or novel filovirus species may have a higher risk of expansion. The latest genomic surveillance is identifying novel filoviruses such as Bombali virus (BOMV) (recently discovered in free-tailed bats in Sierra Leone [3] and Lloviu virus (LLOV) (from Spain [75]). An rVSV BOMV-GP-expressing recombinant pseudovirus was shown to be able to enter permissive cells via the common filovirus receptor (NPC1) but this does not prove pathogenicity in humans. Without any prior evidence of pathogenic infection in humans, the balance of probabilities is weighted against a pathogenic role for such novel animal viruses in humans. As new human pathogens are always emerging 'Disease $X$ ' has now been added to the WHO blueprint of priority diseases [76]. An example of 'Disease $X$ ' might be something like Lujo virus (LUJV) haemorrhagic fever [77]. This novel Arenavirus (the same family as Lassa fever) discovered in Zambia \& South Africa in 2008, killed 4/5 people infected, including three healthcare workers. Our preparedness for future outbreaks must not be blinkered, but must be adaptable, with investments in infrastructure and training having provision for identifying novel pathogens and rapidly developing effective diagnostic assays.

Continued analysis of assays in Table 1 shows that the majority of ebolavirus RT-qPCR assays (both commercial and in-house) use TaqMan probes. Most of them can in theory be performed using multiple thermocycling platforms, although have often only been validated on one or two machines. Likewise, most assays do not have integrated RNA-extraction and so this must be factored in when considering assay performance and the economics of providing laboratory diagnostic services for EVD. Just three RT-PCR assays employ LAMP (loop mediated isothermal amplification) chemistry that is often touted as appropriate for use in low-infrastructure environments, but you still need electricity and a $-20^{\circ} \mathrm{C}$ cold-chain, plus the assays can only be run at established labs by trained biomedical scientists. Only one of the three assays is commercially available; the Benzine - RT-LAMP assay [78](Lucigen Corp). Another characteristic that is often overstated in promotional literature for commercial diagnostic tests for Ebola is turnaround time. Whilst a shorter turnaround time is always preferable, differences of $1-2 \mathrm{hrs}$ are probably not going to be the rate-limiting step in the logistics chain from clinical evaluation through to initiation of appropriate treatment/care, where the availability of healthcare personnel and logistics for sample transport are more likely to be ratelimiting. Effective laboratory diagnostic preparedness for EVD should be anchored in a competent and well-resourced national reference laboratory (that is centrally funded through a national university or government research institute, with active research and training programmes on emerging infectious diseases), which can support a range of assays and can adapt and introduce new assays as appropriate. Whilst the situation might vary depending on the specific geopolitics of the country involved, we feel that for many countries, in the early days of an outbreak response, all specimens should be transported to and processed in this centralized facility. It is only if these initial control efforts fail, that there is really a need for disseminated laboratory diagnostic capacity [79]. The main thrust of preparedness for emerging infections should be to establish surveillance systems and response capacity so that vast deployments of field diagnostics are not required.

\subsection{Rapid Diagnostic Tests (RDTs)}

Table 2 details the descriptive characteristics of nine rapid diagnostic tests (RDTs) for EVD that are under development. The primary requirements for RDTs are that they should be easy to use by 
community health volunteers in the field and that they should be highly sensitive 'rule-out' tests, to triage patients to larger evaluation units for confirmatory testing [41]. But obviously the greater the specificity you can achieve with such tests the better, as each false positive case will be referred to an ebola treatment centre, putting them at high risk of contact with genuine cases. Even if infection control at the treatment centre is working extremely well, the fallout from low specificity being reported in lay media could be detrimental. If people think they are going to be incorrectly diagnosed with ebola it will deter them from seeking care, and fuel suspicion of the public health system $[80,81]$.

Some of these issues are nicely illustrated by efforts to evaluate the performance of the ReEBOV Antigen Rapid test (Zalgen Labs LLC). The PHE-lab in Port Loko, Sierra Leone, published a field validation study in 2015 [54], comparing the performance of the ReEBOV assay against the RealStar ${ }^{\circledast}$ Filovirus Screen RT-PCR Kit 1.0 (Altona Diagnostics). The ReEBOV assay appeared to out-perform the Altona assay, despite the latter having an established LOD over 1000 times lower than the RDT. For operational reasons the study team ran the Altona assay on a platform (SmartCycler II) that the manufacturer knew would give a significantly higher (30-fold) LOD, resulting in the clinical diagnostic sensitivity of the ReEBOV RDT being exaggerated $(100 \%)[82,83]$. Other validation studies delivered sensitivities of $62 \%[84,85]$ and $91.8 \%$ [86], highlighting the challenges of evaluating RDTs in the absence of well-defined gold-standards. EUA for ReEBOV was revoked by FDA on $18^{\text {th }}$ May 2018 following request by the manufacturer, Zalgen Labs [87].

The Ebola eZYSCREEN lateral flow assay developed by BioMérieux and academic partners in France, achieved a very high level of specificity (98.9\%), but a much lower sensitivity (65.3\% on whole blood, $74.5 \%$ on sera). This clinical validation was undertaken in Guinea during the end of the West African epidemic using the RealStar 'Type' assay as gold-standard. The Cq values from the Altona assay did not differ between true positives and false negatives, suggesting there could be some factor independent of viral load that might be affecting the performance of the eZYSCREEN assay. An evaluation of the OraQuick RDT on blood detected only 5/7 PCR positives and 8 PCR-negative specimens were 'false' positive by RDT [88]. The EVD RDTs that have been developed appear to have consistently lower accuracy than RT-qPCR [89], and their use and potential role needs to be carefully considered. It is contingent on key factors, such as the temporal point within an outbreak, the number of suspected Ebola patients being tested and the real prevalence of Ebola within those who are being tested. Operational studies highlight the need for training, even on simple RDTs with relatively straight forward read-outs and for simple algorithms combining RDT and PCR results [54, 88]. Training needs to be repeated regularly to maintain preparedness, with high staff turnover in the medical sector, whilst during an outbreak there might be the need to expand diagnostic services to additional new locations. Another consideration is the potential of POC RDTs to find their way onto the market, where they might be used in the absence of a healthcare professional to ensure the test is done correctly, and to interpret the result [79, 90]. One LAMP-PCR-based assay has conjugated Ebola-specific probes to hCG, so that the assay can be read using an off-the-shelf pregnancy test [91].

\subsection{Metagenomic sequencing based diagnostics}

As we mentioned earlier it is important to have diagnostic tools that are able to identify novel pathogens and be able to study the molecular epidemiology of strains in current outbreaks. Nextgeneration sequencing (NGS) technology has been used to great effect as a surveillance research tool during and after the West African epidemic[92], to shed new light on our understanding of the molecular epidemiology of the ebolavirus during outbreaks [93], giving a fascinatingly detailed insight into the impact of factors like international travel [94], 'super-spreaders' [22] and flare-ups 
arising from persistent viral shedding in survivors [34]. Whole genome sequence (WGS) data has also been used to look at mutations in specific genes that might be associated with virulence or tropism, such as mutations in known b-cell epitopes or cell-binding domains of the ebolavirus GP [95]. Comparative analysis shows that VP24, 30 and 40 are relatively conserved, whereas the GP and L genes show much higher uptake of non-synonymous mutations [96]. Whilst the mutation rate in the West Africa epidemic (1.23 $\left.\times 10^{3} \mathrm{sub} / \mathrm{site} / \mathrm{yr}\right)$ was in line with that observed in previous outbreaks [96-98], the sheer size and scale of the epidemic represents a previously unparalleled number of concurrent replicative passages in human hosts, leading to a sharper increase in genetic diversity than seen in previous outbreaks [98]. WGS data is also of use to diagnostic developers, who can monitor for the emergence of mutations that might affect assay performance [99].

Whilst NGS should continue to be included as an integral component of surveillance efforts [100], it is also increasingly being considered as a possible diagnostic tool for infectious diseases to detect mutations linked with drug resistance and to monitor antiviral therapy $[101,102]$. The expensive platforms and cold-chain reagents required for NGS have largely precluded their use as front-line diagnostic tools in LMICs, but the emergence of nanopore sequencers (Oxford Nanopore) has changed this and an increasing number of research groups are using them to develop diagnostic tools for both viral [103] and bacterial infections [104]. MinION nanopore sequencers were piloted during the West Africa epidemic, using a targeted approach, where viral nucleic acids are enriched by targeted RT-PCR, to ensure sufficient read depth and overcome host background [105]. Nanopore sequencing technology originally required a DNA library, but there has been rampant innovation and the platform now supports direct sequencing of RNA libraries [106]. Furthermore, others have also developed enrichment strategies to aid detection of ebolavirus and other emerging pathogens [107, 108], but the real power of nanopore sequencers in the field, however, is the potential to identify novel viral pathogens at source, without the need to ship-specimens overseas. Clinical specimens such as sera, urine or saliva, can be filtered to isolate virus particles. Nuclease treatment then degrades background host DNA, whilst viral nucleic acid remains protected within the viral particle. Subsequent nucleic acid extraction allows sequencing of the extracellular 'virome' of the clinical specimen of interest [109]. Although not in a diagnostic context, Filoviruses have been effectively concentrated using mini hemopurifiers [110], although translating this 'concentrating' approach to the diagnostic context might raise additional biosafety concerns. Currently, these are still very much research tools, requiring considerable wet-lab and bioinformatics expertise and so after the discovery of a novel etiological agent, one would then want to rapidly design an RT-qPCR or antigenbased assay to detect the target of interest.

\subsection{Novel biosensor approaches}

The age of PCR will probably pass to make way for the new generation of highly sensitive and specific biosensor-based diagnostics that are emerging, using the latest microfluidics and nanotechnology. Recent advances in biosensor technology have led to the production of possible cheap Ebola diagnostics and miniaturisation of these techniques makes it possible to diagnose multiple pathogens on a single chip. One strategy involves magnetic particle-based biosensors [111], where pathogen-specific antibodies, antigens or DNA are conjugated to a magnetic bead, to allow high levels of enrichment for the target of interest. Capillary electrophoresis systems can be engineered to create lab-on-chip microfluidic devices that can efficiently separate and then detect target nucleic acid at down to picomolar concentrations [112]. Peptide nucleic acid probes (PNAs) contain a polyamide backbone that mimics the pentose-phosphodiester backbone of DNA [113]. This makes them more stable and allows them to bind target sequence more tightly. Immuno-PCR (iPCR) is an ELISA-like technique, where the secondary antibody is covalently bound to a DNA target that can then be amplified by PCR [113]. Quartz crystal microbalance (QCM), surface plasmon resonance 
(SPR) and photonic crystal-based label-free immunosensors are other possible approaches that have been recently described elsewhere $[113,114]$.

These novel biosensor technologies are at an early stage of their development and a detailed technical review is beyond the scope of this article, but we thought it would be interesting to highlight one of these technologies, which illustrates a novel approach that might be applicable to filoviruses or other emerging pathogens. Single Particle Interferometric Reflectance Imaging Sensor (SP-IRIS) is potentially a rapid and sensitive diagnostic technique that potentially needs minimal sample preparation or user expertise and can be used to test for multiple pathogens simultaneously. SP-IRIS technology is essentially an enhanced form of light microscopy that allows you to visualise (and hence count) individual virus particles [115]. Virus-specific monoclonal antibodies are conjugated to DNA, which hybridizes with a DNA-spotted sensor surface. The hybridized DNA forms a stem that raises the height of the antibody above the sensor surface, overcoming some of the short-comings of immobilizing antibodies directly to sensor surfaces, where steric hindrance through multiple contacts with the surface or with neighbouring antibodies are known to impair antibodyantigen binding. The sensor chip is visualized with an NVDX10 reader (nanoView Diagnostics) that illuminates the sensor chip at specific wavelengths using an LED light source. This bench-top machine contains a 40X 0.75NA objective and a high spec CMOS (complementary metal-oxide semiconductor) digital camera. A computer then applies a complex algorithm based on averaging multiple images, to construct a composite image and also count the number of virus particles. One chip can be printed with different arrays of DNA-probes to bind mAbs specific for different viruses simultaneously [116]. This DNA-tethering technology increases the sensitivity of the sensor by 6-fold, allowing resolution of individual virus particles. The DNA-printed sensors are resistant to the high temperatures often used in the manufacture of microfluidic POC diagnostic devices and are cheaper to manufacture than antibody-printed sensors [115]. This technology has been successfully piloted to visualise both Ebola virus $[117,118]$ and Zika virus [116] particles. It's conceivable that such a technology could be optimized and developed into a diagnostic tool that is sensitive, specific, rapid and multiplexed.

\section{7 microRNA as biomarkers}

microRNAs (miRNAs) are non-coding nucleotide sequences that function to regulate posttranslational expression of target genes [119]. miRNAs are highly stable in biological fluids and can withstand many freeze-thaw cycles and have been used in cancer diagnosis as well as in the diagnosis of some infectious diseases[120]. They can be used as biomarkers for EVD[121]. Several miRNAs have been predicted for EBOV [119, 121-123]. Three miRNAs have been shown to be most abundant and can be detected before symptoms of EVD begin[124], showing promise for early diagnosis of EVD. Translating these results into a viable diagnostic test is a challenge. There are several things that determine the viability of an assay; the biological sample used, its mode of collection, the method of RNA extraction and the detection method used[120].

\section{Conclusions}

Molecular diagnostics have a key role to play in the control of EVD and other infectious disease outbreaks with pandemic potential. The West Africa epidemic has stimulated a lot of activity, with development or commercialization of previously designed in-house assays, collaborations between commercial partners with complementary intellectual property (marrying 'assay' with 'platform') and the creation of completely new diagnostic products by commercial entities, often adapting chemistry or platforms they have previously developed for other infectious disease threats. There is a range of exciting new biosensor technologies being developed for EVD and other emerging infections, and there is a need to obtain some preliminary validation of these techniques on clinical samples. None of the developmental biosensor technologies have been trialled in the field, whereas 
metagenomic sequencing was piloted during the West Africa outbreak. However, metagenomic approaches are currently best-suited to answering research questions with respect to epidemiology and genomics, or index case pathogen ID and local capacity should be developed through the incorporation of sequencing and pathogen ID into surveillance and training efforts. We are not close to any kind of end-user sequencing-based diagnostic device, comparable with the close-to-POC devices like the GeneXpert or Alere q [79]. There is a dearth of quality studies comparing the analytical and clinical accuracy of these new tests and this can only be addressed through collaborative endeavour and the sharing of resources, such as biobanks. The dual testing approach (triage-confirm), which makes a lot of sense for chronic infectious diseases, particularly TB, is possibly overly cumbersome for EVD outbreaks, where rapid and accurate diagnosis is paramount to stem transmission. The nature of EVD, characterised by very large viral loads in blood, means that both antigen-detection RDTs and field-use PCR platforms could be optimized to sufficient accuracy for outbreak control, providing they are deployed promptly. Key to this is the need for ongoing clinical surveillance, supplemented by reasonably frequent (monthly-quarterly) deployment of national disease control laboratory teams with VHF assays. Such activities could be readily embedded into ongoing national health programmes, such as those for TB, HIV or Malaria, at minimal additional cost.

\subsection{Expert opinion}

Developing appropriate and effective EVD molecular diagnostics for close-to-point-of-care use in resource-limited settings is challenging. Even for established endemic infectious diseases, such as tuberculosis (TB), there are relatively few WHO/FDA approved molecular diagnostic tests. These approvals are supported by large bodies of evidence (Pubmed lists 34 clinical trials on Xpert MTB/RIF, although there is still much debate about how the assay might be best utilized), comprising initial validation studies, through to full-blown clinical trials, including head-to-head trials and more complex trials comparing different diagnostic algorithms and other operational studies. The physical fragility of most thermocycling platforms presents fundamental limitations for their deployment to field clinics, although currently PCR-based assays are inherently more specific than serology-based RDTs. All molecular diagnostic tests for use in LMIC field settings have to be sufficiently sensitive and specific, must be robust and easy to implement with minimal cold-chain or electricity requirements, and they must be affordable. For EVD there are two additional challenges; 1 ) the sporadic nature of the outbreaks means there is not an endemic patient population in which to readily evaluate new diagnostic tests and 2) Ebola virus is a BSL-4 pathogen, which adds considerable complexity to designing diagnostic clinical trials during active outbreaks, in particular, ethical questions of acceptable safety levels for those implementing the trial and concerns for the patients for whom the priority is clinical care. Knowing which of the available diagnostic tests is most accurate could potentially have a big impact on our ability to control outbreaks. The diagnostic response to the current outbreak in the DRC (and other recent outbreaks) utilizes RT-qPCR assays, but the available analytical sensitivity and specificity data has been generated using a range of different methodologies making comparisons very difficult. There is a need for head-to-head comparisons using available biobanks to definitively determine those which are most accurate, ideally incorporating available clinical and epidemiological data. With respect to RDTs, there is even less data available, making any kind of meaningful comparison based on published data impossible. There is a need for coordinated action to evaluate the available diagnostic tools using available biobanks and to incorporate strategies that reduce risk to laboratory and clinical staff during specimen collection and handling. The capacity to undertake clinical accuracy trials during outbreaks should be incorporated into ongoing surveillance activities and protocols written and pre-approved by ethics committees and regulators and pre-approved funding secured, to enable timely implementation during the next EVD outbreak. 
PCR-based molecular diagnostics for Ebolavirus currently dominate, but there have been massive advances in biosensor technology in the last decade and we feel the very nature of Ebola lends itself to the development of these sequence-independent technologies. The analytical sensitivity of molecular diagnostics for Ebolavirus and other known emerging pathogens needs to be determined by independent laboratories, using quality controlled and quality assured protocols and reagents, provided by some central authority (eg, CDC, or the European BSL-4 network). Ideally, the standards or controls used should be non-infectious, such as in-vitro transcripts (IVTs) or non-infectious pseudoviruses, to enable testing without the need for BSL-4 containment. Government BSL-4 labs should then prioritise the best-performing assays, for evaluations using more clinically relevant standards, such as blood spiked with live virus. Development and optimization of POC tests, whether RDTs or field-PCR devices should be the focus, but emerging infectious disease diagnostics should always be handled by health professionals and public health authorities, who can provide confirmatory testing and guide/ensure isolation and treatment of positive cases. In the next five years, we would like to see several head-to-head clinical diagnostic evaluations undertaken using existing biobanks, or those collected from future outbreaks. These studies need to be carefully designed and planned, be considerate to the rights of the patients and the safety of healthcare workers. Funding must be secured and ethics approval must be granted by the appropriate ethics institutions in all equatorial African countries. Such an endeavour should be led by Africa CDC and research groups who are best placed in terms of experience and their close ties with the relevant government institutions should be selected in all countries. In 2018 DRC has suffered back-to-back EVD outbreaks from independent sources and we anticipate more outbreaks, caused by Ebola and/or other novel viruses, as both animal and human populations compete for space and resources in a modernizing Africa.

\section{Funding}

The lead authors (J Tembo \& M Bates) are supported through the EDCTP (European \& Developing Countries Clinical Trials Partnership) on the PANDORA-ID-NET, CANTAM2 and EMPIRICAL projects. The funder was not involved in the preparation, review or approval of the manuscript.

\section{Declaration of interest}

The authors have no relevant affiliations or financial involvement with any organization or entity with a financial interest in or financial conflict with the subject matter or materials discussed in the manuscript. This includes employment, consultancies, honoraria, stock ownership or options, expert testimony, grants or patents received or pending, or royalties

\section{Reviewer disclosures}

Peer reviewers on this manuscript have no relevant financial or other relationships to disclose.

\section{Author contributions}

J Tembo, M Bates, E Simulundu, K Changula all contributed equally, D Handley, M Gilbert helped putting together tables, all other authors helped in writing and editing drafts of this paper.

\section{Acknowledgments}

The authors would like to acknowledge the European Developing Countries Clinical Trials Partnership EDCTP support through the Pan African Network for Rapid Response, Research and Preparedness for Infectious Disease Epidemics PANDORA project. 


\section{References}

Articles or patents of special interest have been highlighted as either of interest $\left({ }^{*}\right)$ or of considerable interest $\left({ }^{* *}\right)$ to readers.

1. Feldmann, H., et al., Fields Virology: p923-956. Philadelphia:

2. Kuhn, J.H., Guide to the Correct Use of Filoviral Nomenclature. Curr Top Microbiol Immunol, 2017. 411: p. 447-460.

3. Goldstein, T., et al., The discovery of Bombali virus adds further support for bats as hosts of ebolaviruses. Nat Microbiol, 2018.

4. Team, W.E.R., et al., After Ebola in West Africa--Unpredictable Risks, Preventable Epidemics. N Engl J Med, 2016. 375(6): p. 587-96.

5. Maurice, J., Expert panel slams WHO's poor showing against Ebola. Lancet, 2015. 386(9990): p. e1.

6. CDC. Ebola Virus Disease Distribution Map: Cases of Ebola Virus Disease in Africa Since 1976. 2018 [cited 2018 19/12/2018]; Available from: https://www.cdc.gov/vhf/ebola/history/distribution-map.html.

7. WHO. WHO ebola virus factsheet 2018 [cited 2018 23rd August]; Available from: http://www.who.int/news-room/fact-sheets/detail/ebola-virus-disease.

8. Fitchett, J.R., et al., Ebola research funding: a systematic analysis, 1997-2015. J Glob Health, 2016. 6(2): p. 020703.

9. Ippolito, G., et al., Ebola: missed opportunities for Europe-Africa research. Lancet Infect Dis, 2015. 15(11): p. 1254-5.

10. Pollock, N.R. and B. Wonderly, Evaluating Novel Diagnostics in an Outbreak Setting: Lessons Learned from Ebola. J Clin Microbiol, 2017. 55(5): p. 1255-1261.

11. Muyembe-Tamfum, J.J., et al., Ebola virus outbreaks in Africa: past and present. Onderstepoort J Vet Res, 2012. 79(2): p. 451.

12. Mari Saez, A., et al., Investigating the zoonotic origin of the West African Ebola epidemic. EMBO Mol Med, 2015. 7(1): p. 17-23.

13. Swanepoel, R., et al., Experimental inoculation of plants and animals with Ebola virus. Emerg Infect Dis, 1996. 2(4): p. 321-5.

14. Olival, K.J. and D.T. Hayman, Filoviruses in bats: current knowledge and future directions. Viruses, 2014. 6(4): p. 1759-88.

15. Leroy, E.M., et al., Fruit bats as reservoirs of Ebola virus. Nature, 2005. 438(7068): p. 575-6.

16. Ogawa, H., et al., Seroepidemiological Prevalence of Multiple Species of Filoviruses in Fruit Bats (Eidolon helvum) Migrating in Africa. J Infect Dis, 2015. 212 Suppl 2: p. S101-8.

17. Laing, E.D., et al., Serologic Evidence of Fruit Bat Exposure to Filoviruses, Singapore, 20112016. Emerg Infect Dis, 2018. 24(1): p. 114-117.

18. Towner, J.S., et al., Marburg virus infection detected in a common African bat. PLoS One, 2007. 2(8): p. e764.

19. Amman, B.R., et al., Seasonal pulses of Marburg virus circulation in juvenile Rousettus aegyptiacus bats coincide with periods of increased risk of human infection. PLoS Pathog, 2012. 8(10): p. e1002877.

20. Olejnik, J., et al., Intracellular events and cell fate in filovirus infection. Viruses, 2011. 3(8): p. 1501-31.

21. Osterholm, M.T., et al., Transmission of Ebola viruses: what we know and what we do not know. MBio, 2015. 6(2): p. e00137. 
22. Lau, M.S., et al., Spatial and temporal dynamics of superspreading events in the 2014-2015 West Africa Ebola epidemic. Proc Natl Acad Sci U S A, 2017. 114(9): p. 2337-2342.

23. Weingartl, H.M., et al., Transmission of Ebola virus from pigs to non-human primates. Sci Rep, 2012. 2: p. 811.

24. Mafopa, N.G., et al., Seroprevalence of Ebola virus infection in Bombali District, Sierra Leone. J Public Health Afr, 2017. 8(2): p. 732.

25. Hoff, N.A., et al., Serologic Markers for Ebolavirus Among Healthcare Workers in the Democratic Republic of the Congo. J Infect Dis, 2019. 219(4): p. 517-525.

26. Glynn, J.R., et al., Asymptomatic infection and unrecognised Ebola virus disease in Ebolaaffected households in Sierra Leone: a cross-sectional study using a new non-invasive assay for antibodies to Ebola virus. Lancet Infect Dis, 2017. 17(6): p. 645-653.

27. Timothy, J.W.S., et al., Early transmission and case fatality of Ebola virus at the index site of the 2013-16 west African Ebola outbreak: a cross-sectional seroprevalence survey. Lancet Infect Dis, 2019.

28. Mulangu, S., et al., Serologic Evidence of Ebolavirus Infection in a Population With No History of Outbreaks in the Democratic Republic of the Congo. J Infect Dis, 2018. 217(4): p. 529-537.

29. Mulangu, S., et al., High prevalence of Ig G antibodies to Ebola virus in the Efe pygmy population in the Watsa region, Democratic Republic of the Congo. BMC Infect Dis, 2016. 16: p. 263.

30. Schoepp, R.J., et al., Undiagnosed acute viral febrile illnesses, Sierra Leone. Emerg Infect Dis, 2014. 20(7): p. 1176-82.

31. Zapata, J.C. and M.S. Salvato, Arenavirus variations due to host-specific adaptation. Viruses, 2013. 5(1): p. 241-78.

32. Pinsky, B.A., et al., Analytical Performance Characteristics of the Cepheid GeneXpert Ebola Assay for the Detection of Ebola Virus. PLoS One, 2015. 10(11): p. e0142216.

33. Akerlund, E., J. Prescott, and L. Tampellini, Shedding of Ebola Virus in an Asymptomatic Pregnant Woman. N Engl J Med, 2015. 372(25): p. 2467-9.

34. Subissi, L., et al., Ebola Virus Transmission Caused by Persistently Infected Survivors of the 2014-2016 Outbreak in West Africa. J Infect Dis, 2018.

35. Mate, S.E., et al., Molecular Evidence of Sexual Transmission of Ebola Virus. N Engl J Med, 2015. 373(25): p. 2448-54.

36. Christie, A., et al., Possible sexual transmission of Ebola virus - Liberia, 2015. MMWR Morb Mortal Wkly Rep, 2015. 64(17): p. 479-81.

37. Sissoko, D., et al., Ebola Virus Persistence in Breast Milk After No Reported Illness: A Likely Source of Virus Transmission From Mother to Child. Clin Infect Dis, 2017. 64(4): p. 513-516.

38. Leroy, E.M., et al., Human asymptomatic Ebola infection and strong inflammatory response. Lancet, 2000. 355(9222): p. 2210-5.

39. Bower, H. and J.R. Glynn, A systematic review and meta-analysis of seroprevalence surveys of ebolavirus infection. Sci Data, 2017. 4: p. 160133.

40. WHO, Laboratory diagnosis of Ebola virus disease. 2014, WHO: Geneva.

41. WHO. Target Product Profile for Zaïre ebolavirus rapid, simple test to be used in the control of the Ebola outbreak in West Africa. 2014 [cited 2018 9th Aug 2018]; Available from: http://www.who.int/medicines/publications/target-product-profile.pdf.

42. Rieger, T., et al., Evaluation of RealStar Reverse Transcription-Polymerase Chain Reaction Kits for Filovirus Detection in the Laboratory and Field. J Infect Dis, 2016. 214(suppl 3): p. S243S249.

43. Nouvellet, P., et al., The role of rapid diagnostics in managing Ebola epidemics. Nature, 2015. 528(7580): p. S109-16.

44. Cherpillod, P., et al., Ebola virus disease diagnosis by real-time RT-PCR: A comparative study of 11 different procedures. J Clin Virol, 2016. 77: p. 9-14. 
45. Strecker, T., et al., Field Evaluation of Capillary Blood Samples as a Collection Specimen for the Rapid Diagnosis of Ebola Virus Infection During an Outbreak Emergency. Clin Infect Dis, 2015. 61(5): p. 669-75.

46. Towner, J.S., et al., Newly discovered ebola virus associated with hemorrhagic fever outbreak in Uganda. PLoS Pathog, 2008. 4(11): p. e1000212.

47. WHO, WHO Emergency Use Assessment: Xpert ${ }^{\circledR}$ Ebola Assay. 2015, WHO: Geneva.

48. WHO, WHO Emergency Use Assessment: FilmArray ${ }^{T M}$ Biothreat-E. 2015, WHO: Geneva.

49. Niedrig, M., et al., First international quality assurance study on the rapid detection of viral agents of bioterrorism. J Clin Microbiol, 2004. 42(4): p. 1753-5.

50. Erickson, B.R., et al., Ebola Virus Disease Diagnostics, Sierra Leone: Analysis of Real-time Reverse Transcription-Polymerase Chain Reaction Values for Clinical Blood and Oral Swab Specimens. J Infect Dis, 2016. 214(suppl 3): p. S258-S262.

51. Ellerbrok, H., et al., External quality assessment study for ebolavirus PCR-diagnostic promotes international preparedness during the 2014 - 2016 Ebola outbreak in West Africa. PLoS Negl Trop Dis, 2017. 11(5): p. e0005570.

52. Kerber, R., et al., Analysis of Diagnostic Findings From the European Mobile Laboratory in Gueckedou, Guinea, March 2014 Through March 2015. J Infect Dis, 2016. 214(suppl 3): p. S250-S257.

53. Rosenke, K., et al., Plasmodium Parasitemia Associated With Increased Survival in Ebola Virus-Infected Patients. Clin Infect Dis, 2016. 63(8): p. 1026-33.

54. Broadhurst, M.J., et al., ReEBOV Antigen Rapid Test kit for point-of-care and laboratorybased testing for Ebola virus disease: a field validation study. Lancet, 2015. 386(9996): p. 867-74.

55. Trombley, A.R., et al., Comprehensive panel of real-time TaqMan polymerase chain reaction assays for detection and absolute quantification of filoviruses, arenaviruses, and New World hantaviruses. Am J Trop Med Hyg, 2010. 82(5): p. 954-60.

56. Logue, C.H., et al., Case study: design and implementation of training for scientists deploying to Ebola diagnostic field laboratories in Sierra Leone: October 2014 to February 2016. Philos Trans R Soc Lond B Biol Sci, 2017. 372(1721).

57. Faye, O., et al., Development and deployment of a rapid recombinase polymerase amplification Ebola virus detection assay in Guinea in 2015. Euro Surveill, 2015. 20(44).

58. Walker, N.F., et al., Evaluation of a point-of-care blood test for identification of Ebola virus disease at Ebola holding units, Western Area, Sierra Leone, January to February 2015. Euro Surveill, 2015. 20(12).

59. Vassall, A., et al., Cost-effectiveness of Xpert MTB/RIF for tuberculosis diagnosis in South Africa: a real-world cost analysis and economic evaluation. Lancet Glob Health, 2017. 5(7): p. e710-e719.

60. FDA, Xpert ${ }^{\circledast}$ Ebola Assay, Instructions for Use, For Use Under an Emergency Use Authorization (EUA) Only. 2015, FDA.

61. Raftery, P., et al., Establishing Ebola Virus Disease (EVD) diagnostics using GeneXpert technology at a mobile laboratory in Liberia: Impact on outbreak response, case management and laboratory systems strengthening. PLoS Negl Trop Dis, 2018. 12(1): p. e0006135.

62. Semper, A.E., et al., Performance of the GeneXpert Ebola Assay for Diagnosis of Ebola Virus Disease in Sierra Leone: A Field Evaluation Study. PLoS Med, 2016. 13(3): p. e1001980.

63. Van den Bergh, R., et al., Feasibility of Xpert Ebola Assay in Medecins Sans Frontieres Ebola Program, Guinea. Emerg Infect Dis, 2016. 22(2): p. 210-6.

64. Pettitt, J., et al., Assessment and Optimization of the GeneXpert Diagnostic Platform for Detection of Ebola Virus RNA in Seminal Fluid. J Infect Dis, 2017. 215(4): p. 547-553. 
65. Panning, M., et al., Diagnostic reverse-transcription polymerase chain reaction kit for filoviruses based on the strain collections of all European biosafety level 4 laboratories. J Infect Dis, 2007. 196 Suppl 2: p. S199-204.

66. Jansen van Vuren, P., et al., Comparative Evaluation of the Diagnostic Performance of the Prototype Cepheid GeneXpert Ebola Assay. J Clin Microbiol, 2016. 54(2): p. 359-67.

67. Mackay, I.M. and K.E. Arden, Ebola virus in the semen of convalescent men. Lancet Infect Dis, 2015. 15(2): p. 149-50.

68. Loftis, A.J., et al., Validation of the Cepheid GeneXpert for Detecting Ebola Virus in Semen. J Infect Dis, 2017. 215(3): p. 344-350.

69. Altona, Instructions for Use RealStar ${ }^{\circledR}$ Zaire Ebolavirus RT-PCR Kit 1.0, A. Diagnostics, Editor. 2017.

70. Jaaskelainen, A.J., et al., Development and evaluation of a real-time EBOV-L-RT-qPCR for detection of Zaire ebolavirus. J Clin Virol, 2015. 67: p. 56-8.

71. Masum, H., R. Lackman, and K. Bartleson, Developing global health technology standards: what can other industries teach us? Global Health, 2013. 9: p. 49.

72. Cnops, L., et al., Development, Evaluation, and Integration of a Quantitative ReverseTranscription Polymerase Chain Reaction Diagnostic Test for Ebola Virus on a Molecular Diagnostics Platform. J Infect Dis, 2016. 214(suppl 3): p. S192-S202.

73. Dedkov, V.G., et al., Sensitive Multiplex Real-time RT-qPCR Assay for the Detection of Filoviruses. Health Secur, 2018. 16(1): p. 14-21.

74. Butler, D., Speedy Ebola tests help contain Africa's latest outbreak. Nature, 2018. 558(7709): p. 172.

75. Negredo, A., et al., Discovery of an ebolavirus-like filovirus in europe. PLoS Pathog, 2011. 7(10): p. e1002304.

76. WHO, 2018 Annual review of diseases prioritized under the Research and Development Blueprint. 2018, WHO: Geneva.

77. Simulundu, E., et al., Lujo viral hemorrhagic fever: considering diagnostic capacity and preparedness in the wake of recent Ebola and Zika virus outbreaks. Rev Med Virol, 2016. 26(6): p. 446-454.

78. Benzine, J.W., et al., Molecular Diagnostic Field Test for Point-of-Care Detection of Ebola Virus Directly From Blood. J Infect Dis, 2016. 214(suppl 3): p. S234-S242.

79. Kost, G.J., Molecular and point-of-care diagnostics for Ebola and new threats: National POCT policy and guidelines will stop epidemics. Expert Rev Mol Diagn, 2018. 18(7): p. 657-673.

80. Pellecchia, U., et al., Social Consequences of Ebola Containment Measures in Liberia. PLoS One, 2015. 10(12): p. e0143036.

81. Editor, T., Ebola in west Africa: gaining community trust and confidence. Lancet, 2014. 383(9933): p. 1946.

82. Broadhurst, M.J., et al., ReEBOV Antigen Rapid Test kit for Ebola - Authors' reply. Lancet, 2015. 386(10010): p. 2255-6.

83. Olschlager, S. and M. Hess, ReEBOV Antigen Rapid Test kit for Ebola. Lancet, 2015. 386(10010): p. 2254.

84. Urassa, W., R. Meurant, and D. Wood, ReEBOV Antigen Rapid Test kit for Ebola. Lancet, 2015. 386(10010): p. 2253-4.

85. Boisen, M.L., et al., Field Validation of the ReEBOV Antigen Rapid Test for Point-of-Care Diagnosis of Ebola Virus Infection. J Infect Dis, 2016. 214(suppl 3): p. S203-S209.

86. WHO, WHO Emergency Use Assessment: ReEBOV ${ }^{\text {TM }}$ Antigen Rapid Test Kit. 2015, WHO: Geneva.

87. FDA. Historical Information about Device Emergency Use Authorizations. 2018 [cited 2018 3rd Sept]; Available from: https://www.fda.gov/MedicalDevices/Safety/EmergencySituations/ucm418778.htm. 
88. VanSteelandt, A., et al., Operational evaluation of rapid diagnostic testing for Ebola Virus Disease in Guinean laboratories. PLoS One, 2017. 12(11): p. e0188047.

89. Phan, J.C., et al., Lateral Flow Immunoassays for Ebola Virus Disease Detection in Liberia. J Infect Dis, 2016. 214(suppl 3): p. S222-S228.

90. Kost, G.J., et al., Molecular detection and point-of-care testing in Ebola virus disease and other threats: a new global public health framework to stop outbreaks. Expert Rev Mol Diagn, 2015. 15(10): p. 1245-59.

91. Du, Y., et al., Coupling Sensitive Nucleic Acid Amplification with Commercial Pregnancy Test Strips. Angew Chem Int Ed Engl, 2017. 56(4): p. 992-996.

92. Hoenen, T., et al., Nanopore Sequencing as a Rapidly Deployable Ebola Outbreak Tool. Emerg Infect Dis, 2016. 22(2): p. 331-4.

93. Gire, S.K., et al., Genomic surveillance elucidates Ebola virus origin and transmission during the 2014 outbreak. Science, 2014. 345(6202): p. 1369-72.

94. Dudas, G., et al., Virus genomes reveal factors that spread and sustained the Ebola epidemic. Nature, 2017. 544(7650): p. 309-315.

95. Capobianchi, M.R., et al., Molecular Signature of the Ebola Virus Associated with the Fishermen Community Outbreak in Aberdeen, Sierra Leone, in February 2015. Genome Announc, 2015. 3(5).

96. Carroll, M.W., et al., Temporal and spatial analysis of the 2014-2015 Ebola virus outbreak in West Africa. Nature, 2015. 524(7563): p. 97-101.

97. Hoenen, T., et al., Virology. Mutation rate and genotype variation of Ebola virus from Mali case sequences. Science, 2015. 348(6230): p. 117-9.

98. Tong, Y.G., et al., Genetic diversity and evolutionary dynamics of Ebola virus in Sierra Leone. Nature, 2015. 524(7563): p. 93-6.

99. Reusken, C., et al., Identification of essential outstanding questions for an adequate European laboratory response to Ebolavirus Zaire West Africa 2014. J Clin Virol, 2015. 62: p. 124-34.

100. Gardy, J.L. and N.J. Loman, Towards a genomics-informed, real-time, global pathogen surveillance system. Nat Rev Genet, 2018. 19(1): p. 9-20.

101. Pankhurst, L.J., et al., Rapid, comprehensive, and affordable mycobacterial diagnosis with whole-genome sequencing: a prospective study. Lancet Respir Med, 2016. 4(1): p. 49-58.

102. Hamers, R.L. and R. Paredes, Next-generation sequencing and HIV drug resistance surveillance. Lancet HIV, 2016. 3(12): p. e553-e554.

103. Greninger, A.L., et al., Rapid metagenomic identification of viral pathogens in clinical samples by real-time nanopore sequencing analysis. Genome Med, 2015. 7: p. 99.

104. Schmidt, K., et al., Identification of bacterial pathogens and antimicrobial resistance directly from clinical urines by nanopore-based metagenomic sequencing. J Antimicrob Chemother, 2017. 72(1): p. 104-114.

105. Quick, J., et al., Real-time, portable genome sequencing for Ebola surveillance. Nature, 2016. 530(7589): p. 228-232.

106. Keller, M.W., et al., Direct RNA Sequencing of the Coding Complete Influenza A Virus Genome. Sci Rep, 2018. 8(1): p. 14408.

107. Brinkmann, A., et al., Development and preliminary evaluation of a multiplexed amplification and next generation sequencing method for viral hemorrhagic fever diagnostics. PLoS Negl Trop Dis, 2017. 11(11): p. e0006075.

108. Koehler, J.W., et al., Development and evaluation of a panel of filovirus sequence capture probes for pathogen detection by next-generation sequencing. PLoS One, 2014. 9(9): $p$. e107007.

109. Altan, E., et al., Enteric virome of Ethiopian children participating in a clean water intervention trial. PLoS One, 2018. 13(8): p. e0202054. 
110. Koch, B., et al., Lectin Affinity Plasmapheresis for Middle East Respiratory SyndromeCoronavirus and Marburg Virus Glycoprotein Elimination. Blood Purif, 2018. 46(2): p. 126133.

111. Rosenstierne, M.W., et al., Rapid Bedside Inactivation of Ebola Virus for Safe Nucleic Acid Tests. J Clin Microbiol, 2016. 54(10): p. 2521-9.

112. Ostromohov, N., O. Schwartz, and M. Bercovici, Focused upon hybridization: rapid and high sensitivity detection of DNA using isotachophoresis and peptide nucleic acid probes. Anal Chem, 2015. 87(18): p. 9459-66.

113. Coarsey, C.T., et al., Strategies in Ebola virus disease (EVD) diagnostics at the point of care. Crit Rev Microbiol, 2017. 43(6): p. 779-798.

114. Yu, J.S., et al., Detection of Ebola virus envelope using monoclonal and polyclonal antibodies in ELISA, surface plasmon resonance and a quartz crystal microbalance immunosensor. I Virol Methods, 2006. 137(2): p. 219-28.

115. Seymour, E., et al., DNA-Directed Antibody Immobilization for Enhanced Detection of Single Viral Pathogens. Anal Chem, 2015. 87(20): p. 10505-12.

116. Daaboul, G.G., et al., Enhanced light microscopy visualization of virus particles from Zika virus to filamentous ebolaviruses. PLoS One, 2017. 12(6): p. e0179728.

117. Carter, E.P., et al., Visualizing Ebolavirus Particles Using Single-Particle Interferometric Reflectance Imaging Sensor (SP-IRIS). Methods Mol Biol, 2017. 1628: p. 259-270.

118. Scherr, S.M., et al., Disposable cartridge platform for rapid detection of viral hemorrhagic fever viruses. Lab Chip, 2017. 17(5): p. 917-925.

119. Liang, H., et al., Identification of Ebola virus microRNAs and their putative pathological function. Sci China Life Sci, 2014. 57(10): p. 973-81.

120. Correia, C.N., et al., Circulating microRNAs as Potential Biomarkers of Infectious Disease. Front Immunol, 2017. 8: p. 118.

121. Chen, Z., et al., An Ebola virus-encoded microRNA-like fragment serves as a biomarker for early diagnosis of Ebola virus disease. Cell Res, 2016. 26(3): p. 380-3.

122. Teng, Y., et al., Systematic Genome-wide Screening and Prediction of microRNAs in EBOV During the 2014 Ebolavirus Outbreak. Sci Rep, 2015. 5: p. 9912.

123. Fu, Z., Liang, H., Zen, K., Zhang C, Chen, X., microRNAs and the Ebola Virus. 2018.

124. Duy, J., et al., Virus-encoded miRNAs in Ebola virus disease. Sci Rep, 2018. 8(1): p. 6480.

125. Altona, Instructions for Use RealStar ${ }^{\circledast}$ Filovirus Screen RT-PCR Kit 1.0, A. Diagnostics, Editor. 2017.

126. WHO, WHO Emergency Use Assessment: RealStar ${ }^{\circledR}$ Filovirus Screen RT-PCR Kit 1.0. 2015, WHO: Geneva.

127. Wang, G., et al., The evaluation of 7 commercial real-time PCR kits for Zaire ebolavirus using virus-like particle-encapsulated EBOV RNA. Diagn Microbiol Infect Dis, 2015. 83(4): p. 355-8.

128. BioFire Defense, L., FilmArray ${ }^{\circledR}$ BioThreat-E Instructions for Use, L. BioFire Defense, Editor. 2016, BioFire Defense, LLC.

129. Southern, T.R., et al., Comparison of FilmArray and Quantitative Real-Time Reverse Transcriptase PCR for Detection of Zaire Ebolavirus from Contrived and Clinical Specimens. J Clin Microbiol, 2015. 53(9): p. 2956-60.

130. BioFire Defense, L., FilmArray ${ }^{\circledR}$ NGDS BT-E Assay Instructions for Use, L. BioFire Defense, Editor. 2016, BioFire Defense, LLC.

131. Roche, LightMix ${ }^{\circledR}$ Ebola Zaire rRT-PCR Test Instruction Manual, Roche, Editor. 2018, Roche.

132. Ltd, P.B.C. Ebola virus (Zaire type) nucleic acid detection kit (PCR fluorescent probe method). 2018 [cited 2018 18th July 2018]; Available from: http://en.szprk.com/prod view.aspx?Typeld=77\&Id=183\&Fld=t3:77:3.

133. NMRC, Ebola Zaire (EZ1) rRT-PCR (TaqMan $\left.{ }^{\circledR}\right)$ Assay Instruction Manual, N.M.R.C.f.T.U.S.D.o. Defense, Editor. 2014. 
134. de Wit, E., et al., Ebola Laboratory Response at the Eternal Love Winning Africa Campus, Monrovia, Liberia, 2014-2015. J Infect Dis, 2016. 214(suppl 3): p. S169-S176.

135. CDC, Ebola Virus NP Real-Time RT-PCR Assay - Instructions for Use. 2016, CDC: Atlanta.

136. CDC, Ebola Virus VP40 Real-Time RT-PCR Assay - Instructions for Use. 2016, CDC: Atlanta.

137. $\mathrm{Xu}, \mathrm{C}$., et al., Visual detection of Ebola virus using reverse transcription loop-mediated isothermal amplification combined with nucleic acid strip detection. Arch Virol, 2016. 161(5): p. 1125-33.

138. Kurosaki, Y., et al., Development and evaluation of a simple assay for Marburg virus detection using a reverse transcription-loop-mediated isothermal amplification method. J Clin Microbiol, 2010. 48(7): p. 2330-6.

139. James, A.S., et al., Ebolavirus diagnosis made simple, comparable and faster than molecular detection methods: preparing for the future. Virol J, 2018. 15(1): p. 75.

140. Magro, L., et al., Paper-based RNA detection and multiplexed analysis for Ebola virus diagnostics. Sci Rep, 2017. 7(1): p. 1347.

141. Towner, J.S., et al., Rapid diagnosis of Ebola hemorrhagic fever by reverse transcription-PCR in an outbreak setting and assessment of patient viral load as a predictor of outcome. J Virol, 2004. 78(8): p. 4330-41.

142. Moschos, S.A., Introducing EbolaCheck: potential for point-of-need infectious disease diagnosis. Expert Rev Mol Diagn, 2015. 15(10): p. 1237-40.

143. Gallais, F., et al., [Field assessment of the new rapid diagnostic test Ebola eZYSCREEN(R)]. Bull Soc Pathol Exot, 2017. 110(1): p. 38-48.

144. Cross, R.W., et al., Analytical Validation of the ReEBOV Antigen Rapid Test for Point-of-Care Diagnosis of Ebola Virus Infection. J Infect Dis, 2016. 214(suppl 3): p. S210-S217.

145. Ikegami, T., et al., Antigen capture enzyme-linked immunosorbent assay for specific detection of Reston Ebola virus nucleoprotein. Clin Diagn Lab Immunol, 2003. 10(4): p. 552-7.

146. Boisen, M.L., et al., Development of Prototype Filovirus Recombinant Antigen Immunoassays. J Infect Dis, 2015. 212 Suppl 2: p. S359-67.

147. Jean Louis, F., et al., Implementation of broad screening with Ebola rapid diagnostic tests in Forecariah, Guinea. Afr J Lab Med, 2017. 6(1): p. 484.

148. Yen, C.W., et al., Multicolored silver nanoparticles for multiplexed disease diagnostics: distinguishing dengue, yellow fever, and Ebola viruses. Lab Chip, 2015. 15(7): p. 1638-41.

149. W.H.O, WHO Emergency Use Assessment and Listing for EVD IVDs PUBLIC REPORT Product: SD Q Line Ebola Zaire Ag Number: EA 0021-020-00

2015.

150. Yoshida, R., et al., Development of an Immunochromatography Assay (QuickNavi-Ebola) to Detect Multiple Species of Ebolaviruses. J Infect Dis, 2016. 214(suppl 3): p. S185-S191.

\section{Table legends}

Table 1: RT-qPCR tests for the detection of Ebola and other filoviruses

Table 2: Rapid Diagnostic Tests (RDTs) for the detection of Ebola and other filoviruses 
Table 1: RT-qPCR tests for the detection of Ebola and other filoviruses

\begin{tabular}{|c|c|c|c|c|c|c|c|c|}
\hline Test Name & Manufacturer & Target & Chemistry & $\begin{array}{l}\text { LOD (RNA copies/ml, unless } \\
\text { otherwise stated) }\end{array}$ & $\begin{array}{l}\text { Turnarou } \\
\text { nd Time } \\
\text { (Min) }\end{array}$ & $\begin{array}{l}\text { Storage } \\
\text { Temp }\end{array}$ & $\begin{array}{l}\text { Platform/ } \\
\text { s }\end{array}$ & $\begin{array}{l}\text { RNA } \\
\text { extractio } \\
\mathbf{n}\end{array}$ \\
\hline \multicolumn{9}{|l|}{ Commercial Assays } \\
\hline $\begin{array}{l}\text { RealStar }{ }^{\circledR} \text { Filovirus } \\
\text { Screen RT-PCR Kit } 1.0 \\
\text { Human pathogenic } \\
\text { Filovirus species }\end{array}$ & $\begin{array}{l}\text { Altona } \\
\text { Diagnostics, } \\
\text { Germany }\end{array}$ & $\begin{array}{l}\text { Pan- } \\
\text { species } \\
\text { EBOV \& } \\
\text { MARV } \\
\text { RNA }\end{array}$ & TM & $\begin{array}{l}\text { EBOV RNA: } 1,390 \text { [125] } \\
\text { Inactivated EBOV spiked WB: } 509 \\
\text { [32].EBOV RNA: } 1250 \text { [44] } \\
\text { EBOVIVT (RG): } 1100 \text { [42] } \\
\text { EBOV IVT (SCII): } 10^{4}[42]\end{array}$ & $\begin{array}{l}190-220 \\
\text { mins }[44]\end{array}$ & $-20^{\circ} \mathrm{C}$ & \multirow{3}{*}{$\begin{array}{l}\text { Mx } \\
\text { VS } \\
A B I \\
\text { LCII } \\
\text { RG } \\
C X\end{array}$} & \multirow{3}{*}{$\begin{array}{l}\text { QIA } \\
\text { QIS } \\
\text { NUC } \\
\text { MAG } \\
\text { ABB } \\
\text { MAX }\end{array}$} \\
\hline $\begin{array}{l}\text { RealStar }^{\circledR} \text { Filovirus } \\
\text { Type RT-PCR Kit } 1.0 \\
\text { Filoviruses and } \\
\text { species } \\
\text { differentiation }\end{array}$ & $\begin{array}{l}\text { Altona } \\
\text { Diagnostics, } \\
\text { Germany }\end{array}$ & $\begin{array}{l}\text { All } 5 \\
\text { EBOV } \\
\text { species } \\
\text { and } \\
\text { MARV } \\
\text { RNA }\end{array}$ & TM & EBOV RNA: $6250[4$ & $\begin{array}{l}190-220 \\
\operatorname{mins}[44]\end{array}$ & $-20^{\circ} \mathrm{C}$ & & \\
\hline $\begin{array}{l}\text { RealStar }{ }^{\oplus} \text { Zaire } \\
\text { Ebolavirus RT-PCR kit } \\
1.0\end{array}$ & $\begin{array}{l}\text { Altona } \\
\text { Diagnostics, } \\
\text { Germany }\end{array}$ & $\begin{array}{l}\text { EBOV } \\
\text { RNA }\end{array}$ & TM & $N R$ & NR & $-20^{\circ} \mathrm{C}$ & & \\
\hline Xpert Ebola & Cepheid, U.S & $\begin{array}{l}\text { EBOV } \\
\text { RNA }\end{array}$ & & $\begin{array}{l}\text { EBOV SpikedWB } 232 \text { [32] } \\
\text { EBOV spiked WB } 275 \text { [68] } \\
\text { EBOV spiked Se } 1000 \text { [68] } \\
\text { Inactivated EBOV Spiked WB } 73 \\
\text { [32] } \\
\text { EBOV spiked WB } 82 \text { [47] } \\
\text { EBOV Virus: } 0.13 \text { PFU/ml } \\
\text { Spiked Se: } 100 \mathrm{PFU/ml} \mathrm{[64]}\end{array}$ & $\begin{array}{l}98-120 \\
\text { minutes }\end{array}$ & $2-8^{\circ} \mathrm{C}$ & $\begin{array}{l}\text { GeneXper } \\
\text { t Only }\end{array}$ & $\begin{array}{l}\text { Integrate } \\
\text { d }\end{array}$ \\
\hline $\begin{array}{l}\text { Liferiver }^{\text {TM }} \text { - Ebola } \\
\text { Virus (EBOV) Real } \\
\text { Time RT-PCR Kit [126] }\end{array}$ & $\begin{array}{l}\text { Shanghai ZJ } \\
\text { BioTech, China }\end{array}$ & $\begin{array}{l}\text { EBOV } \\
\text { RNA }\end{array}$ & TM & $\begin{array}{l}24 \\
677[127]\end{array}$ & $\begin{array}{l}\text { Results in } \\
2 \text { hours, } \\
\text { total } \\
\text { processin } \\
\text { g } 240- \\
360 \text { mins }\end{array}$ & $-20^{\circ} \mathrm{C}$ & Any & Any \\
\hline
\end{tabular}




\begin{tabular}{|c|c|c|c|c|c|c|c|c|}
\hline $\begin{array}{l}\text { Idylla }{ }^{\mathrm{TM}} \text { prototype } \\
\text { Ebola virus test } \\
{[72]}\end{array}$ & $\begin{array}{l}\text { Biocartis \& } \\
\text { Janssen } \\
\text { Diagnostics, } \\
\text { Belgium }\end{array}$ & $\begin{array}{l}\text { EBOV \& } \\
\text { SUDV } \\
\text { RNA }\end{array}$ & NR & $\begin{array}{l}\text { EBOV Spiked WB: 1010, } 465 \\
\text { PFU/ml } \\
\text { SUDV Spiked WB: 8204, } 324 \\
\text { PFU/ml }\end{array}$ & $\begin{array}{l}97 \\
\text { minutes }\end{array}$ & $-20^{\circ} \mathrm{C}$ & Idylla only & $\begin{array}{l}\text { Integrate } \\
\text { d }\end{array}$ \\
\hline $\begin{array}{l}\text { FilmArray }{ }^{\oplus} \text { BioThreat- } \\
\text { E test }\end{array}$ & $\begin{array}{l}\text { BioFire } \\
\text { Defense, U.S } \\
\text { (bioMérieux, } \\
\text { France) }\end{array}$ & $\begin{array}{l}\text { EBOV } \\
\text { RNA }\end{array}$ & $\begin{array}{l}\text { LCGreen }^{\circledR} \\
\text { Plus } \\
\text { Multiplex } \\
\text { PCR Array }\end{array}$ & $\begin{array}{l}\text { Spiked TC spnts 4059/Rxn [48] } \\
\text { Inactivated EBOV in WB: } \\
6 \times 10^{5} \mathrm{PFU} / \mathrm{ml}[128] \\
400 \mathrm{TCID}_{50} / \mathrm{ml}[129]\end{array}$ & $\begin{array}{l}60 \text { mins } \\
{[128]}\end{array}$ & $15-25^{\circ} \mathrm{C}$ & $\begin{array}{l}\text { FilmArray } \\
\text { System } \\
\text { Only }\end{array}$ & $\begin{array}{l}\text { Integrate } \\
\text { d }\end{array}$ \\
\hline $\begin{array}{l}\text { FilmArray NGDS BT-E } \\
\text { Assay [130] }\end{array}$ & $\begin{array}{l}\text { BioFire } \\
\text { Defense, U.S } \\
\text { (bioMérieux, } \\
\text { France) }\end{array}$ & $\begin{array}{l}\text { EBOV } \\
\text { RNA }\end{array}$ & $\begin{array}{l}\text { LCGreen }^{\circledR} \\
\text { Plus } \\
\text { Multiplex } \\
\text { PCR Array }\end{array}$ & $\begin{array}{l}\text { With live virus } \\
\text { WB } 10^{4} \mathrm{PFU} / \mathrm{ml} \\
400 \mathrm{TCID}_{50} / \mathrm{ml}[129]\end{array}$ & 60 mins & $15-25^{\circ} \mathrm{C}$ & $\begin{array}{l}\text { FilmArray } \\
\text { System } \\
\text { Only }\end{array}$ & $\begin{array}{l}\text { Integrate } \\
\text { d }\end{array}$ \\
\hline FTD $^{\circledR}$ Ebola [44] & $\begin{array}{l}\text { Fast-track } \\
\text { Diagnostics, } \\
\text { Malta }\end{array}$ & $\begin{array}{l}\text { EBOV } \\
\text { RNA }\end{array}$ & TM & 625 & $\begin{array}{l}145-175 \\
\text { mins }\end{array}$ & $-20^{\circ} \mathrm{C}$ & Any & Any \\
\hline $\begin{array}{l}\text { Lifetech Lyophilized } \\
\text { Ebola Virus (Zaire } \\
\text { 2014) }\end{array}$ & $\begin{array}{l}\text { Life } \\
\text { Technologies, } \\
\text { U.S }\end{array}$ & $\begin{array}{l}\text { EBOV } \\
\text { RNA }\end{array}$ & TM & & $\begin{array}{l}105-130 \\
\operatorname{mins}[44]\end{array}$ & $\begin{array}{l}2-8^{\circ} \mathrm{C} \\
\text { storage! }\end{array}$ & Any & Any \\
\hline $\begin{array}{l}\text { Benzine - RT-LAMP } \\
\text { [78] }\end{array}$ & $\begin{array}{l}\text { Lucigen Corp, } \\
\text { U.S }\end{array}$ & $\begin{array}{l}\text { EBOV } \\
\text { RNA }\end{array}$ & & $\begin{array}{l}\text { IVT: } 10^{4} \\
\text { Spiked WB: } 10^{3} \text { PFU/test }\end{array}$ & 40 mins & $\begin{array}{l}\text { Lyophili } \\
\text { zed } \\
\text { reagent } \\
\text { s: } 15- \\
25^{\circ} \mathrm{C}\end{array}$ & IQ5 & $\begin{array}{l}\text { In-house } \\
\text { rapid } \\
\text { prep[78] }\end{array}$ \\
\hline $\begin{array}{l}\text { LightMix Ebola Zaire } \\
\text { rRT-PCR Test }\end{array}$ & $\begin{array}{l}\text { Roche, } \\
\text { Switzerland }\end{array}$ & $\begin{array}{l}\text { EBOV } \\
\text { RNA }\end{array}$ & TM & $\begin{array}{l}1250[44] \\
4781 \mathrm{PFU} / \mathrm{ml}[131]\end{array}$ & $\begin{array}{l}150-185 \\
\operatorname{mins}[44]\end{array}$ & $4-24^{\circ} \mathrm{C}$ & LCII & ROC \\
\hline $\begin{array}{l}\text { Detection Kit for } \\
\text { Ebola virus subtype } \\
\text { Zaire RNA [132] }\end{array}$ & $\begin{array}{l}\text { Puruikang } \\
\text { Biotech Co. Ltd, } \\
\text { China }\end{array}$ & $\begin{array}{l}\text { EBOV } \\
\text { RNA }\end{array}$ & TM & $\begin{array}{l}10^{3} \\
104[127]\end{array}$ & NR & $-20^{\circ} \mathrm{C}$ & $\begin{array}{l}\text { CX } \\
\text { LCII } \\
\text { SLA }\end{array}$ & Any \\
\hline $\begin{array}{l}\text { AccuPower EBOV } \\
\text { Real-Time RT-PCR Kit }\end{array}$ & $\begin{array}{l}\text { Bloneer, South } \\
\text { Korea }\end{array}$ & $\begin{array}{l}\text { EBOV } \\
\text { RNA }\end{array}$ & NR & 48 copies/test & NR & $-20^{\circ} \mathrm{C}$ & EXI & Any \\
\hline $\begin{array}{l}\text { AccuPower EBOV } \\
\text { Quantitative RT-PCR } \\
\text { Kit }\end{array}$ & $\begin{array}{l}\text { Bloneer, South } \\
\text { Korea }\end{array}$ & $\begin{array}{l}\text { EBOV } \\
\text { RNA }\end{array}$ & NR & NR & NR & $-20^{\circ} \mathrm{C}$ & EXI & Any \\
\hline
\end{tabular}




\begin{tabular}{|c|c|c|c|c|c|c|c|c|c|}
\hline \multicolumn{2}{|c|}{$\begin{array}{l}\text { AmpliSens }{ }^{\circledR} \text { EBOV } \\
\text { Zaire-FL [73] }\end{array}$} & $\begin{array}{l}\text { Central } \\
\text { Research } \\
\text { Institute for } \\
\text { Epidemiology, } \\
\text { Russia }\end{array}$ & $\begin{array}{l}\text { EBOV } \\
\text { RNA }\end{array}$ & TM & 500 & 90 mins & $-20^{\circ} \mathrm{C}$ & NR & NR \\
\hline \multicolumn{2}{|c|}{$\begin{array}{l}\text { OM-Screen- } \\
\text { ZEBOV/SUDV/MARV- } \\
\text { RV [73] }\end{array}$} & $\begin{array}{l}\text { Sintol Ltd., } \\
\text { Russia }\end{array}$ & $\begin{array}{l}\text { EBOV, } \\
\text { SUDV \& } \\
\text { MARV } \\
\text { RNA }\end{array}$ & NR & 1000 & & $-20^{\circ} \mathrm{C}$ & NR & NR \\
\hline \multicolumn{10}{|c|}{ In-house Assays } \\
\hline \multicolumn{2}{|c|}{$\begin{array}{l}\text { EZ1 Real Time PCR } \\
\text { Assay[133] }\end{array}$} & $\begin{array}{l}\text { Naval Medical } \\
\text { Research } \\
\text { Center for The } \\
\text { U.S. } \\
\text { Department of } \\
\text { Defence }\end{array}$ & $\begin{array}{l}\text { EBOV } \\
\text { RNA }\end{array}$ & TM & $1000-5000$ & NR & $-20^{\circ} \mathrm{C}$ & $\begin{array}{l}\text { ABI } \\
\text { LCII } \\
\text { JBAIDS }\end{array}$ & QIA \\
\hline \multirow{7}{*}{ 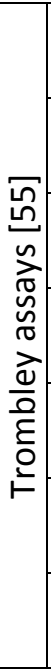 } & Ebola Zaire-TM GP & \multirow{7}{*}{$\begin{array}{l}\text { U.S Army } \\
\text { Medical } \\
\text { Research } \\
\text { Institute of } \\
\text { Infectious } \\
\text { Diseases } \\
\text { (USAMRIID), } \\
\text { Special } \\
\text { Pathogens } \\
\text { Laboratory }\end{array}$} & $\begin{array}{l}\text { EBOV } \\
\text { RNA }\end{array}$ & TM & $\begin{array}{l}584 \\
0.0001 \text { PFU/Rxn }\end{array}$ & NR & $-20^{\circ} \mathrm{C}$ & $\mathrm{LCII}$ & $\begin{array}{l}\mathrm{AMB} \\
\mathrm{EZ1}\end{array}$ \\
\hline & $\begin{array}{l}\text { Ebola Zaire-MGB } \\
\text { NP }\end{array}$ & & $\begin{array}{l}\text { EBOV } \\
\text { RNA }\end{array}$ & TM-MGB & 0.001 PFU/Rxn & NR & $-20^{\circ} \mathrm{C}$ & $\mathrm{LCII}$ & $\begin{array}{l}\mathrm{AMB} \\
\mathrm{EZ1}\end{array}$ \\
\hline & $\begin{array}{l}\text { Ebola Sudan-TM } \\
\text { GP } \\
\end{array}$ & & $\begin{array}{l}\text { SUDV } \\
\text { RNA }\end{array}$ & TM & $0.1 \mathrm{PFU} / \mathrm{Rxn}$ & NR & $-20^{\circ} \mathrm{C}$ & $\mathrm{LCII}$ & $\begin{array}{l}\mathrm{AMB} \\
\mathrm{EZ1}\end{array}$ \\
\hline & $\begin{array}{l}\text { Ebola Sudan-MGB } \\
\text { NP }\end{array}$ & & $\begin{array}{l}\text { SUDV } \\
\text { RNA }\end{array}$ & TM-MGB & $0.1 \mathrm{PFU} / \mathrm{Rxn}$ & NR & $-20^{\circ} \mathrm{C}$ & $\mathrm{LCll}$ & $\begin{array}{l}\mathrm{AMB} \\
\mathrm{EZ1}\end{array}$ \\
\hline & $\begin{array}{l}\text { Ebola Ivory Coast- } \\
\text { TM GP } \\
\end{array}$ & & $\begin{array}{l}\text { TAFV } \\
\text { RNA }\end{array}$ & TM & $0.1 \mathrm{PFU} / \mathrm{Rxn}$ & NR & $-20^{\circ} \mathrm{C}$ & LCII & $\begin{array}{l}\mathrm{AMB} \\
\mathrm{EZ1}\end{array}$ \\
\hline & $\begin{array}{l}\text { Ebola Ivory Coast- } \\
\text { MGB GP }\end{array}$ & & $\begin{array}{l}\text { TAFV } \\
\text { RNA } \\
\end{array}$ & TM-MGB & $\begin{array}{l}586 \\
1 \mathrm{PFU} / \mathrm{Rxn}\end{array}$ & NR & $-20^{\circ} \mathrm{C}$ & LCII & $\begin{array}{l}\text { AMB } \\
\text { EZ1 }\end{array}$ \\
\hline & $\begin{array}{l}\text { Ebola Bundibugyo } \\
\text { (MGB and TM) NP }\end{array}$ & & $\begin{array}{l}\text { BDBV } \\
\text { RNA }\end{array}$ & TM-MGB & NR & NR & $-20^{\circ} \mathrm{C}$ & $\mathrm{LCII}$ & $\begin{array}{l}\mathrm{AMB} \\
\mathrm{EZ1}\end{array}$ \\
\hline \multicolumn{2}{|c|}{$\begin{array}{l}\text { Ebola Virus L Real } \\
\text { PCR }\end{array}$} & $\begin{array}{l}\text { Centre for } \\
\text { Disease Control } \\
\text { - National }\end{array}$ & $\begin{array}{l}\text { EBOV } \\
\text { RNA }\end{array}$ & ZEN-TM & NR & 150 mins & $-20^{\circ} \mathrm{C}$ & $\mathrm{SCll}$ & $\begin{array}{l}\text { DYN } \\
\text { MAG } \\
\text { QIA }\end{array}$ \\
\hline
\end{tabular}




\begin{tabular}{|c|c|c|c|c|c|c|c|c|}
\hline $\begin{array}{l}\text { Ebola Virus GP } \\
\text { Real PCR }\end{array}$ & \multirow{3}{*}{$\begin{array}{l}\text { Institute for } \\
\text { Allergy \& } \\
\text { Infectious } \\
\text { Diseases, U.S }\end{array}$} & $\begin{array}{l}\text { EBOV } \\
\text { RNA }\end{array}$ & ZEN-TM & NR & 150 mins & $-20^{\circ} \mathrm{C}$ & JBAID & $\begin{array}{l}\text { DYN } \\
\text { MAG } \\
\text { QIA }\end{array}$ \\
\hline $\begin{array}{l}\text { Ebola Virus NP } \\
\text { Real PCR [134, } \\
135]\end{array}$ & & $\begin{array}{l}\text { EBOV } \\
\text { RNA }\end{array}$ & ZEN-TM & $\begin{array}{l}\text { WB6000 TCID }{ }_{50} / \mathrm{ml} \\
\text { U6000 TCID } \\
400 / \mathrm{ml} \\
\mathrm{TCID}_{50} / \mathrm{ml}[129]\end{array}$ & $150 \mathrm{mins}$ & $-20^{\circ} \mathrm{C}$ & $\begin{array}{l}A B I \\
C X\end{array}$ & $\begin{array}{l}\text { DYN } \\
\text { MAG } \\
\text { QIA }\end{array}$ \\
\hline $\begin{array}{l}\text { Ebola Virus VP40 } \\
\text { Real PCR [134, } \\
136]\end{array}$ & & $\begin{array}{l}\text { EBOV } \\
\text { RNA }\end{array}$ & NR & $\begin{array}{l}\text { WB600 TCID } 50 / \mathrm{ml} \\
\text { U600 TCID } 50 / \mathrm{ml} \\
400 \mathrm{TCID}_{50} / \mathrm{ml}[129]\end{array}$ & & $-20^{\circ} \mathrm{C}$ & $\begin{array}{l}\mathrm{ABI} \\
\mathrm{CX}\end{array}$ & $\begin{array}{l}\text { DYN } \\
\text { MAG } \\
\text { QIA }\end{array}$ \\
\hline $\begin{array}{l}\text { Xu - RT-LAMP-NAD } \\
\text { [137] }\end{array}$ & $\begin{array}{l}\text { Academy of } \\
\text { Military } \\
\text { Medical } \\
\text { Sciences, China }\end{array}$ & $\begin{array}{l}\text { EBOV } \\
\text { RNA }\end{array}$ & LAMP & $\begin{array}{l}\text { IVT: } 30 \\
\text { IVT: } 10^{2} \mathrm{TCl}\end{array}$ & 40 mins & $-20^{\circ} \mathrm{C}$ & $\begin{array}{l}\text { Any heat } \\
\text { block but } \\
\text { NAD } \\
\text { required } \\
\text { for } \\
\text { imaging } \\
\text { (U-Star } \\
\text { Biotechno } \\
\text { logies) }\end{array}$ & Any \\
\hline $\begin{array}{l}\text { Kurosaki - RT-LAMP } \\
\text { [138] }\end{array}$ & $\begin{array}{l}\text { Nagasaki } \\
\text { University, } \\
\text { Japan }\end{array}$ & $\begin{array}{l}\text { EBOV } \\
\text { RNA }\end{array}$ & LAMP & & 60 mins & $-20^{\circ} \mathrm{C}$ & $\begin{array}{l}\text { GE3 } \\
\text { LA2 }\end{array}$ & QIA \\
\hline RPA-LFS [139] & $\begin{array}{l}\text { University } \\
\text { of the Sunshine } \\
\text { Coast, Australia }\end{array}$ & $\begin{array}{l}\text { EBOV } \\
\text { RNA }\end{array}$ & RPA & $1.34 \times 10^{4}$ & 30 mins & & $\begin{array}{l}\text { Any heat } \\
\text { block }\end{array}$ & REY \\
\hline $\begin{array}{l}\text { RT-RPA Ebola Assay } \\
\text { [140] }\end{array}$ & $\begin{array}{l}\text { Institut Pasteur, } \\
\text { France }\end{array}$ & $\begin{array}{l}\text { EBOV } \\
\text { RNA }\end{array}$ & RPA & $10^{10}$ copies $/ \mathrm{ml}$ & 20 mins & $\begin{array}{l}\text { Room } \\
\text { Temp }\end{array}$ & $\begin{array}{l}\text { Heat } \\
\text { block } \\
\text { Leica } \\
\text { macrosco } \\
\text { pe and } \\
\text { light } \\
\text { source }\end{array}$ & Any \\
\hline Towner assay [141] & $\begin{array}{l}\text { Centre for } \\
\text { Disease }\end{array}$ & $\begin{array}{l}\text { SUDV } \\
\text { RNA }\end{array}$ & $\mathrm{TM}$ & NR & NR & $-20^{\circ} \mathrm{C}$ & $\mathrm{ABI}$ & $\mathrm{PCH}$ \\
\hline
\end{tabular}




\begin{tabular}{|c|c|c|c|c|c|c|c|c|}
\hline & Control, U.S & & & & & & & \\
\hline $\begin{array}{l}\text { Vector-PCR } \text { RV-Ebola- }_{\text {E }} \\
\text { RG }\end{array}$ & $\begin{array}{l}\text { "Vector» } \\
\text { Russia }\end{array}$ & $\begin{array}{l}\text { EBOV } \\
\text { and/or } \\
\text { SUDV }\end{array}$ & TM & 2000 & $\begin{array}{l}\text { 240- } \\
\text { 360mins }\end{array}$ & $-20^{\circ} \mathrm{C}$ & NR & NR \\
\hline EBOV-L RT-qPCR [70] & $\begin{array}{l}\text { University of } \\
\text { Helsinki, } \\
\text { Finland }\end{array}$ & $\begin{array}{l}\text { EBOV, } \\
\text { SUDV \& } \\
\text { BDBV } \\
\text { RNA }\end{array}$ & TM & NR & & & & \\
\hline EbolaCheck [142] & $\begin{array}{l}\text { US Army } \\
\text { Medical } \\
\text { Research } \\
\text { Institute of } \\
\text { Infectious } \\
\text { disease, U.S } \\
\text { Public Health } \\
\text { England, U.K } \\
\text { Kwame } \\
\text { Nkrumah } \\
\text { University of } \\
\text { Science and } \\
\text { Technology, } \\
\text { Ghana }\end{array}$ & EBOV & NR & $10^{4}$ genome equivalents $/ \mathrm{ml}$ & 40 mins & None & $\begin{array}{l}\text { Ebolachec } \\
\mathrm{k} \\
\text { Instrume } \\
\text { nt(portabl } \\
\mathrm{e} \\
\text { thermocy } \\
\text { cler) }\end{array}$ & $\begin{array}{l}\text { integrate } \\
\text { d }\end{array}$ \\
\hline
\end{tabular}

For ease of legibility all percentages are rounded to the nearest whole number and confidence limits have been excluded. See links to referenced articles if more detailed data are required.

EUA - FDA Emergency Use Authorization. WB (Whole blood), fpWB (finger prick whole blood), Sa (Saliva), Se (Semen), U (Urine), TC spnts (Tissue culture supernatants). Number pre-fix specimen type indicates number of specimens. IVT - in vitro transcripts, TCID $_{50}$ (Tissue culture infectious dose 50 ), PFU (plaque forming units),

Chemistries: TM = Taqman, LAMP = Loop mediated isothermal amplification, RPA - Recombinase polymerase amplification, ZEN-TM (Taqman using doublequenching to reduce background signal and increase sensitivity, TM-MGB = Taqman Major Groove binder.

PCR Platforms: Mx = Mx 3005 TM $^{\mathrm{TM}}$ QPCR System (Stratagene), VS $=$ Versant ${ }^{\circledR}$ kPCR Molecular System AD (Siemens), ABI = ABI Prism ${ }^{\circledR} 7500$ SDS OR 7500 Fast SDS (Applied Biosystems), LCII = LightCycler ${ }^{\circledR} 480$ Instrument II (Roche), SCII = SmartCycler II (Cepheid), RG = Rotor-Gene ${ }^{\mathrm{TM}} 3000 / 6000$ (Corbett Research) or 
Rotor-Gene Q 5/6 plex Platform (QIAGEN), CX = CFX96 system/Dx real-time system (Bio-Rad), IQ5 = IQ5, BioRad, GE3 = Genie III (OptiGene), LA2 = LA-200 (Eiken), EXI = ExiStation ${ }^{T M}$ Universal Molecular Diagnostic System or Exicycler ${ }^{T M}$ 96, SLA - SLAN-96P (Shanghai Hongshi Medical Technology)

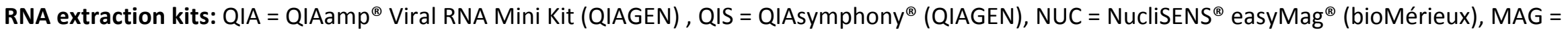

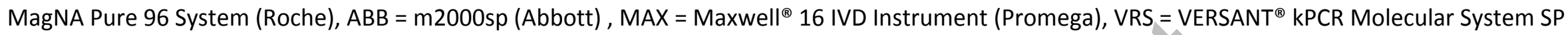
(Siemens Healthcare), DYN = Dynal BeadRetriever ${ }^{\mathrm{TM}}$ System, REY = RNeasy Mini Kit (QIAGEN), EZ1 = EZ1 Virus Mini Kit V 2.0 (QIAGEN), ROC = High Pure Viral Nucleic Acid Kit (Roche), AMB = Ambion MagMAX ${ }^{\mathrm{TM}}$ Viral RNA Isolation Kit (Ambion, Austin, TX), PCH = Phenol/Chloroform in house method.

Inclusion of primer and probe sequences was beyond the scope of this paper, but where they are available, see linked reference. See [99] for detailed analysis of known mutations in different ebola virus genes.

Table 2: Rapid Diagnostic Tests (RDTs) for the detection of Ebola and other filoviruses

\begin{tabular}{|c|c|c|c|c|c|c|c|}
\hline Test Name & Manufacturer & Target & 95\% LOD & $\begin{array}{l}\text { Turnaround } \\
\text { Time (Min) }\end{array}$ & $\begin{array}{l}\text { Storage } \\
\text { Temp }\end{array}$ & Platform/s & Sample \\
\hline $\begin{array}{l}\text { Ebola } \\
\text { eZYSCREEN[143] }\end{array}$ & $\begin{array}{l}\text { Institut des } \\
\text { sciences du } \\
\text { vivant Frédéric } \\
\text { Joliot, France }\end{array}$ & EBOV GP & $10^{5} \mathrm{PFU} / \mathrm{ml}$ & 15 minutes & $4-30^{\circ} \mathrm{C}$ & None & $\begin{array}{l}\text { Whole } \\
\text { blood/plasma }\end{array}$ \\
\hline $\begin{array}{l}\text { ReEBOV Antigen } \\
\text { Rapid Test[54, 144] }\end{array}$ & $\begin{array}{l}\text { Zalgen Labs } \\
\text { (previously } \\
\text { Corgenix Ltd), } \\
\text { U.S }\end{array}$ & $\begin{array}{l}\text { EBOV, SUDV \& } \\
\text { BDBV VP40 } \\
\text { antigen }\end{array}$ & $\begin{array}{l}6.25 \mathrm{E}+02 \\
\mathrm{ng} / \mathrm{ml} \text { Ebola } \\
\text { rVP40 antigen } \\
10^{6} \mathrm{PFU} / \mathrm{ml}\end{array}$ & 15 minutes & $2-8{ }^{\circ} \mathrm{C}$ & None & $\begin{array}{l}\text { Whole blood } \\
\text { /plasma }\end{array}$ \\
\hline $\begin{array}{l}\text { ELISA antigen capture } \\
\text { [145] }\end{array}$ & $\begin{array}{l}\text { National Institute } \\
\text { of Infectious } \\
\text { Diseases, Japan }\end{array}$ & $\begin{array}{l}\text { Reston Ebola } \\
\text { virus } \\
\text { Nucleoprotein }\end{array}$ & NR & Hours & $2-8^{\circ} \mathrm{C}$ & $\begin{array}{l}\text { Biotek ELISA } \\
\text { plate } \\
\text { reader(or any } \\
\text { other } \\
\text { comparable } \\
\text { plate reader) }\end{array}$ & Serum \\
\hline $\begin{array}{l}\text { Ebola specific } \\
\text { IgM and IgG antibody } \\
\text { detection [146] }\end{array}$ & Corgenix, U.S & $\begin{array}{l}\text { EVD specific } \\
\text { antibodies } \\
\text { against VP40 } \\
\text { antigen }\end{array}$ & NR & Hours & $2-8^{\circ} \mathrm{C}$ & $\begin{array}{l}\text { Biotek ELISA } \\
\text { plate reader } \\
\text { (or any other } \\
\text { comparable } \\
\text { plate reader) }\end{array}$ & Serum \\
\hline
\end{tabular}




\begin{tabular}{|c|c|c|c|c|c|c|c|}
\hline OraQuick RDT [147] & $\begin{array}{l}\text { OraSure } \\
\text { Technologies Inc, } \\
\text { U.S }\end{array}$ & $\begin{array}{l}\text { Ebola Virus } \\
\text { Antigens } \\
\text { Kost } 2015 \\
\text { detects SUDV } \\
\text { \& BDBV }\end{array}$ & $\begin{array}{l}53 \mathrm{ng} / \mathrm{ml} \text { or } \\
1.06 \mathrm{ng} / \mathrm{test} \\
\text { (in spiked } \\
\text { whole blood) }\end{array}$ & 20-30 minutes & $4-30^{\circ} \mathrm{C}$ & None & $\begin{array}{l}\text { Whole Blood/ } \\
\text { Oral fluid } \\
\text { specimen } \\
\text { (cadaveric) }\end{array}$ \\
\hline DSTL EVD RDT [58] & $\begin{array}{l}\text { United } \\
\text { Kingdom's } \\
\text { Defence Science } \\
\text { and Technology } \\
\text { Laboratory }\end{array}$ & $\begin{array}{l}\text { EVD } \\
\text { antigen }\end{array}$ & NR & 20 minutes & & None & Whole blood \\
\hline $\begin{array}{l}\text { Matrix Multiplexed } \\
\text { Diagnostic [148] }\end{array}$ & MMDx & EVD antigen & $150 \mathrm{ng} / \mathrm{ml}$ & $10 \mathrm{minu}$ & NR & None & $\begin{array}{l}\text { NR } \\
\text { (Plasma/Seru } \\
\text { m) }\end{array}$ \\
\hline $\begin{array}{l}\text { SD Q Line Ebola Zaire } \\
\mathrm{Ag}[149]\end{array}$ & $\begin{array}{l}\text { SD Biosensor Inc, } \\
\text { Republic of } \\
\text { Korea }\end{array}$ & $\begin{array}{l}\text { Ebola Zaire } \\
\text { antigen (GP, } \\
\text { NP and VP40) }\end{array}$ & NR & 30 minutes & $1-40^{\circ} \mathrm{C}$ & None & Plasma \\
\hline $\begin{array}{l}\text { QuickNavi-Ebola } \\
\text { [150] }\end{array}$ & $\begin{array}{l}\text { Denka Seiken, } \\
\text { Japan }\end{array}$ & $\begin{array}{l}\text { EBOV, TAFV, } \\
\text { BDBV NP }\end{array}$ & $N R$ & 10 minutes & $4-45^{\circ} \mathrm{C}$ & None & $\begin{array}{l}\text { Whole } \\
\text { blood/serum/ } \\
\text { plasma }\end{array}$ \\
\hline iSENSE & $\begin{array}{l}\text { University } \\
\text { College London }\end{array}$ & $\begin{array}{l}\text { EBOV SUDV } \\
\text { BDBV IgG }\end{array}$ & NR & 40 minutes & NR & None & Venous Blood \\
\hline
\end{tabular}

